\title{
The Prion Protein Ligand, Stress-Inducible Phosphoprotein 1, Regulates Amyloid- $\beta$ Oligomer Toxicity
}

\author{
Valeriy G. Ostapchenko, ${ }^{1,2}$ Flavio H. Beraldo, ${ }^{1,2}$ Amro H. Mohammad, ${ }^{1,3}$ Yu-Feng Xie, ${ }^{1,2}$ Pedro H. F. Hirata, ${ }^{1,5}$ \\ Ana C. Magalhaes, ${ }^{1,3}$ Guillaume Lamour, ${ }^{6,7}$ Hongbin Li, ${ }^{6}$ Andrzej Maciejewski, ${ }^{4}$ Jillian C. Belrose, ${ }^{1,3}$ Bianca L. Teixeira, ${ }^{5}$ \\ Margaret Fahnestock, ${ }^{8}$ Sergio T. Ferreira, ${ }^{9}$ Neil R. Cashman, ${ }^{7}$ Glaucia N. M. Hajj, ${ }^{5}$ Michael F. Jackson, ${ }^{1,2}$ \\ Wing-Yiu Choy, ${ }^{4}$ John F. MacDonald, ${ }^{1,2,3}$ Vilma R. Martins, ${ }^{5}$ Vania F. Prado, ${ }^{1,2,3}$ and Marco A. M. Prado ${ }^{1,2,3}$ \\ ${ }^{1}$ Robarts Research Institute, Departments of ${ }^{2}$ Physiology and Pharmacology, ${ }^{3}$ Anatomy and Cell Biology, and ${ }^{4}$ Biochemistry, The University of Western \\ Ontario, London, Ontario, Canada N6A 5K8, 5Department of Molecular and Cell Biology, International Research Center, A. C. Camargo Cancer Center and \\ National Institute for Translational Neuroscience, São Paulo, São Paulo, Brazil, 01508-010, ${ }^{6}$ Chemistry Department and ${ }^{7}$ Brain Research Center, University \\ of British Columbia, Vancouver, British Columbia, Canada V6T 1Z4, ${ }^{8}$ Department of Psychiatry and Behavioural Neurosciences, McMaster University, \\ Hamilton, Ontario, Canada L8S 4K1, ${ }^{9}$ Institute of Medical Biochemistry, Federal University of Rio de Janeiro, Rio de Janeiro, Rio de Janeiro, Brazil, \\ 21941-590
}

In Alzheimer's disease $(\mathrm{AD})$, soluble amyloid- $\beta$ oligomers $(\mathrm{A} \beta 0 \mathrm{~s})$ trigger neurotoxic signaling, at least partially, via the cellular prion protein $\left(\operatorname{PrP}^{\mathrm{C}}\right)$. However, it is unknown whether other ligands of $\operatorname{PrP}^{\mathrm{C}}$ can regulate this potentially toxic interaction. Stress-inducible phosphoprotein 1 (STI1), an Hsp90 cochaperone secreted by astrocytes, binds to $\operatorname{PrP}^{\mathrm{C}}$ in the vicinity of the $\mathrm{A} \beta 0$ binding site to protect neurons against toxic stimuli. Here, we investigated a potential role of STI1 in A $\beta 0$ toxicity. We confirmed the specific binding of A $\beta 0$ s and STI1 to the PrP and showed that STI1 efficiently inhibited A $\beta 0$ binding to PrP in vitro (IC ${ }_{50}$ of $\left.\sim 70 \mathrm{nM}\right)$ and also decreased $\mathrm{A} \beta 0$ binding to cultured mouse primary hippocampal neurons. Treatment with STI1 prevented A $\beta 0$-induced synaptic loss and neuronal death in mouse cultured neurons and long-term potentiation inhibition in mouse hippocampal slices. Interestingly, STI1haploinsufficient neurons were more sensitive to $\mathrm{A} \beta 0$-induced cell death and could be rescued by treatment with recombinant STI1. Noteworthy, both $\mathrm{A} \beta 0$ binding to $\operatorname{PrP}^{\mathrm{C}}$ and $\operatorname{PrP}^{\mathrm{C}}$-dependent $\mathrm{A} \beta 0$ toxicity were inhibited by TPR2A, the $\operatorname{PrP}^{\mathrm{C}}$-interacting domain of STI1. Additionally, $\operatorname{PrP}^{\mathrm{C}}$-STI1 engagement activated $\alpha 7$ nicotinic acetylcholine receptors, which participated in neuroprotection against $\mathrm{A} \beta 0$-induced toxicity. We found an age-dependent upregulation of cortical STI1 in the APPswe/PS1dE9 mouse model of AD and in the brains of $\mathrm{AD}$-affected individuals, suggesting a compensatory response. Our findings reveal a previously unrecognized role of the PrP $\mathrm{C}^{\mathrm{C}}$ ligand STI1 in protecting neurons in AD and suggest a novel pathway that may help to offset $\mathrm{A} \beta 0$-induced toxicity.

\section{Introduction}

Neuronal dysfunction in Alzheimer's disease (AD) is related to accumulation of soluble oligomers of the amyloid- $\beta$ peptide (AßOs; Lambert et al., 1998; Walsh et al., 2002; Ferreira and Klein, 2011; Mucke and Selkoe, 2012). Interaction of these toxic

Received July 29, 2013; revised Sept. 3, 2013; accepted Sept. 7, 2013.

Author contributions: V.G.O., F.H.B., J.F.M., V.R.M., V.F.P., and M.A.M.P. designed research; V.G.O., F.H.B., A.H.M., Y.-F.X., P.H.F.H., A.C.M., G.L., B.L.T., and G.N.M.H. performed research; A.M., J.C.B., M.F., S.T.F., N.R.C., and W.-Y.C. contributed unpublished reagents/analytic tools; V.G.O., F.H.B., A.H.M., Y.-F.X., P.H.F.H., A.C.M., G.L., H.L., G.N.M.H., M.F.J., W.-Y.C., J.F.M., V.R.M., V.F.P., and M.A.M.P. analyzed data; V.G.O., V.F.P., and M.A.M.P. wrote the paper.

This work was supported by the Alzheimer's Association, PrioNet-Canada, Canadian Institutes of Health Research Grant MOP 93651, São Paulo State Foundation (FAPESP) Grants 2009/14027-2 (V.R.M.) and 2012/04370-4 (G.N.M.H.), National Institute for Translational Neuroscience, Canadian Foundation for Innovation, and Ontario Research Fund. A.H.M. and A.M. were recipients of Master's Program Ontario Graduate Scholarship. B.L.T. received an FAPESP fellowship. We thank PrP ${ }^{5}$, a PrioNet-Canada facility, and David Wishart for the gift of PrP 112-231.

The authors declare no competing interests.

Correspondence should be addressed to Dr. Marco A.M. Prado, Robarts Research Institute, 100 Perth Drive, London, Ontario, Canada N6A 5K8. E-mail: mprado@robarts.ca.

M.F. Jackson's present address: Department of Pharmacology and Therapeutics, Kleysen Institute for Advanced Medicine, University of Manitoba, Winnipeg, Manitoba, Canada R3E 0T6.

DOI:10.1523/JNEUROSCI.3214-13.2013

Copyright $\odot 2013$ the authors $\quad 0270-6474 / 13 / 3316552-13 \$ 15.00 / 0$ particles with several distinct types of receptors in neurons (Wang et al., 2000; Xie et al., 2002; Laurén et al., 2009; Decker et al., 2010) triggers glutamate excitotoxicity, synaptic dysfunction, inhibition of long-term potentiation (LTP), and neuronal death (Querfurth and LaFerla, 2010; Paula-Lima et al., 2013). The exact mechanisms underlying each of these effects are not fully understood, but toxic actions of $\mathrm{A} \beta \mathrm{O}$ s seem to depend, at least in part, on the cellular prion protein ( $\operatorname{PrP}^{\mathrm{C}}$; Laurén et al., 2009; Gimbel et al., 2010; Bate and Williams, 2011; Kudo et al., 2012).

$\mathrm{PrP}^{\mathrm{C}}$ is a master regulator of cellular signaling (Martins et al., 2010), likely by scaffolding distinct ligands and neuronal transmembrane receptors (Linden et al., 2008; Beraldo et al., 2010, 2011; Santos et al., 2013). Interaction of $A \beta O$ with the $\operatorname{PrP}^{C}$ region comprising amino acid residues 95-105 appears critical for neuronal toxicity (Laurén et al., 2009; Chung et al., 2010; Barry et al., 2011; Freir et al., 2011). Accordingly, disrupting A $\beta O$ binding to $\operatorname{PrP}^{\mathrm{C}}$ seems to alleviate $\operatorname{PrP}^{\mathrm{C}}$-dependent $\mathrm{A} \beta \mathrm{O}$ toxicity. For example, antibodies targeting $\mathrm{PrP}^{\mathrm{C}}$ prevent synaptic plasticity deficits induced by A $\beta$ Os (Chung et al., 2010; Barry et al., 2011; Freir et al., 2011). However, $\operatorname{PrP}^{\mathrm{C}}$ antibodies can lead to toxicity by triggering neuronal signaling (Solforosi et al., 2004). 
Therefore, endogenous physiological ligands of $\operatorname{PrP}^{\mathrm{C}}$ may provide an alternative means of modulating $\mathrm{A} \beta \mathrm{O}$-induced toxicity.

Stress-inducible phosphoprotein 1 (STI1) is a cochaperone secreted by astrocytes that can interact with and signal via $\operatorname{PrP}^{\mathrm{C}}$ (Zanata et al., 2002; Lopes et al., 2005; Lima et al., 2007; Caetano et al., 2008; Roffé et al., 2010; Hajj et al., 2013). STI1 binds to PrP ${ }^{\mathrm{C}}$ at residues 113-128 (Chiarini et al., 2002; Zanata et al., 2002), adjacent to the $\mathrm{A} \beta \mathrm{O}$ binding site, leading to reciprocal conformational changes in both proteins (Romano et al., 2009). Extracellular STI1 forms a signaling complex with $\operatorname{PrP}^{\mathrm{C}}$ in hippocampal neurons that promotes calcium influx through $\alpha 7$ nicotinic acetylcholine receptors ( $\alpha 7 \mathrm{nAChR}$; Beraldo et al., 2010). This in turn triggers several signaling pathways that protect neurons from apoptosis (Lopes et al., 2005; Caetano et al., 2008; Beraldo et al., 2010; Roffé et al., 2010). Importantly, both $\operatorname{PrP}^{\mathrm{C}}$ and $\alpha 7 \mathrm{nAChR}$ are recognized targets of $\mathrm{A} \beta$ peptides (Wang et al., 2000, 2009; Magdesian et al., 2005; Laurén et al., 2009; Um et al., 2012). Interestingly, recent system biology approaches have implicated differential expression of the STI1 gene (STIP1) in AD (Zhang et al., 2013). Moreover, a loss-of-function STI1 mutation increases Tau toxicity in a fly model of tauopathy (Ambegaokar and Jackson, 2011).

Here, we provide evidence supporting a role for STI1regulated pathways in $\mathrm{AD}$. We find that STI1 inhibited $\mathrm{A} \beta \mathrm{O}$ binding to $\operatorname{PrP}$ and to cells expressing $\operatorname{PrP}^{\mathrm{C}}$. In addition, toxic effects mediated by $\mathrm{A} \beta \mathrm{O}$ could be prevented by STI1 in a $\operatorname{PrP}^{\mathrm{C}}$ and $\alpha 7 \mathrm{nAChR}$-dependent way. Our results suggest that altered levels of STI1 in individuals with $\mathrm{AD}$ may influence $\mathrm{A} \beta \mathrm{O}$ induced neuronal toxicity.

\section{Materials and Methods}

Mouse lines. Genetically modified $S T I 1^{-/+}$mice were generated by standard homologous recombination techniques (Prado et al., 2006), using C57BL/6j ES cells, as described previously (Beraldo et al., 2013). In mammals, elimination of STI1 causes early embryonic lethality; hence, $S T I 1^{-/+}$neurons were used here (Beraldo et al., 2013). Prnp ${ }^{-/-}$mice in a C57BL/6j background were kindly donated by Dr. Frank Jirik (University of Calgary, Calgary, Alberta, Canada) (Tsutsui et al., 2008). APPswe/ PS1dE9 (Jankowsky et al., 2001) and $\alpha 7 n A C h R^{-/-}$(Orr-Urtreger et al., 1997) mice in a C57BL/6j background were obtained from The Jackson Laboratory. Procedures were conducted in accordance with approved animal use protocols at the University of Western Ontario (2008/127) and the A. C. Camargo Hospital (037/09) following Canadian Council of Animal Care and National Institutes of Health guidelines.

Preparation of proteins and peptides. Recombinant mouse PrP with an $\mathrm{N}$-terminal His tag was produced in Escherichia coli strain BL21(DE3). For this, bacteria were transformed with pRSET/PrP plasmid DNA kindly provided by Prof. Kurt Wüthrich (ETH Zürich, Zürich, Switzerland). PrP was expressed in inclusion bodies that were solubilized in $8 \mathrm{M}$ urea and $20 \mathrm{~mm}$ Tris-HCl, $\mathrm{pH} 8.0$, and purified using $\mathrm{Ni}^{2+}$-affinity chromatography. After that, $\operatorname{PrP}$ was refolded by dialysis against $10 \mathrm{~mm} \mathrm{NaOAc}, 10 \mathrm{~mm}$ 2-mercaptoethanol, and $1 \mathrm{~mm}$ EDTA, $\mathrm{pH} 5.0$, and stored for $<10 \mathrm{~d}$ at $4^{\circ} \mathrm{C}$. Recombinant mouse $\operatorname{PrP}(112-231)$ peptide was provided by the $\operatorname{PrP}^{5}$ PrioNet facility (University of Alberta, Edmonton, Canada). Recombinant STI1 was produced as a (His) ${ }_{6}$-SUMO-tag-fused protein by cloning STI1 cDNA into $\mathrm{pE}-\mathrm{SUMO}$ vector (Lifesensors) and transforming E. coli strain BL21(DE3) with the obtained pE-SUMO-STI1 plasmid DNA. After initial purification using $\mathrm{Ni}^{2+}$-affinity chromatography, the (His) ${ }_{6}-\mathrm{SUMO}$ tag was cleaved off using SUMO Pro enzyme (Lifesensors), and untagged STI1 was obtained by a second $\mathrm{Ni}^{2+}$-affinity purification step. Pure STI1 was stored for less than a week at $4^{\circ} \mathrm{C}$ or fast-frozen in liquid nitrogen and stored at $-80^{\circ} \mathrm{C}$ for $1-2$ months. TPR2A and its $230-245$ amino acid deletion variant (TPR2A $\Delta_{230-245}$ ) were produced as $\mathrm{N}$-terminal His-tag constructs in E. coli strain BL21(DE3) transformed with pDEST17 vector (Invitrogen) containing the correspondent gene. After cleavage with His-TEV protease, (His) ${ }_{6}$ tag and the protease were removed by $\mathrm{Ni}^{2+}$-affinity purification, and the untagged peptides were stored for $<10 \mathrm{~d}$ at $4^{\circ} \mathrm{C}$. Quality of protein preparations, including Hsp90 (Cayman Chemical) and lysozyme (SigmaAldrich), was routinely checked using 4-20\% SDS-PAGE gels (Lonza) stained for protein bands with RapidStain reagent (EMD Millipore), which allows $100 \mathrm{ng}$ resolution. Circular dichroism (CD) spectra measured as described previously (Ostapchenko et al., 2008) were used to assess the quality of recombinant proteins. The presence of lipopolysaccharides in protein preparations was tested using ToxinSensor Endotoxin Assay Kit (GenScript); no more than 0.2 endotoxin units (EU) of E. coli endotoxin equivalent was present in our preparations. $A \beta O$ s were prepared from $A \beta_{1-42}$ peptide (rPeptide) similarly to a previously described procedure (Caetano et al., 2011). Briefly, the peptide was monomerized in hexafluoroisopropanol, dried in a SpeedVac centrifuge, restored in DMSO to $1 \mathrm{~mm}$ solution, and diluted in PBS (CD and LTP experiments) or F-12 medium (all other experiments) to the final concentration of $100 \mu \mathrm{M}$ (hereafter monomer concentration used as $\mathrm{A} \beta \mathrm{O}$ concentration). After incubation for $24 \mathrm{~h}$ at $4^{\circ} \mathrm{C}, \mathrm{A} \beta \mathrm{Os}$ were cleared by centrifugation when needed and either used immediately or stored at $-80^{\circ} \mathrm{C}$ for no more than a few weeks. Peptide preparation quality was checked by several methods. Western blot with 6E10 (1:2000; Covance) antibody was done by a standard technique after peptide separation on $13.5 \%$ Tris-tricine SDS-PAGE and electrotransfer to polyvinyl difluoride membrane. CD spectra were obtained from $25 \mu \mathrm{M}$ A $\beta \mathrm{O}$ using a J810 spectropolarimeter (Jasco) equipped with a $1 \mathrm{~mm}$ cuvette, with five scans averaged for each resulting spectra. Size-exchange chromatography was done using ÄKTA-FPLC (GE Healthcare) equipped with a Superdex 75 column (GE Healthcare) following the procedure described previously (Larson et al., 2012). For atomic force microscopy (AFM), A $\beta O$ preparations were diluted to $0.1 \mu \mathrm{M}$, deposited on a freshly cleaved piece of mica for $10 \mathrm{~min}$, and dried under a nitrogen stream. Images were acquired in tapping mode using a Cypher AFM (Asylum Research) mounted with silicon tips (AC160TS; from Olympus; nominal spring constant of $40 \mathrm{~N} / \mathrm{m}$ ). Section analyses were performed using the AFM software to determine the height of the species imaged. Their corresponding molecular weight was determined via a calibration curve describing the AFM heights of proteins of known molecular weight. Scrambled $\mathrm{A} \beta_{1-42}$ peptide (rPeptide) was prepared following the same procedure as for the $\mathrm{A} \beta \mathrm{O}$ preparation.

Surface plasmon resonance. Surface plasmon resonance (SPR) experiments were performed using the Biacore X system (GE Healthcare) equipped with either a nitrilotriacetic acid (NTA) or CM5 sensor chip. The NTA chip was first charged with nickel ions and then uniformly covered with either PrP or STI1 bearing (His) ${ }_{6}$ tags with SPR signal of $\sim 10,000$ resonance units (RU). The CM5 chip was prepared by a standard amine-coupling procedure (Fischer, 2010). All ligands were injected in $25 \mathrm{~mm}$ HEPES, $150 \mathrm{~mm} \mathrm{NaCl}$, and $10 \mathrm{~mm}$ imidazole, $\mathrm{pH}$ 7.0, at $5 \mu \mathrm{l} / \mathrm{min}$, and on-kinetics were registered for $6 \mathrm{~min}$. After each injection, off-kinetics were followed for $2 \mathrm{~min}$. The chip surface was regenerated between injections by a short injection of $10 \mathrm{~mm} \mathrm{HCl}$. SPR curves for STI1 and A $\beta O$ binding to PrP were analyzed using a simple bimolecular binding model with GraphPad Software Prism linear (for initial binding rates), exponential decay (for off-kinetics), and "one-site binding" (to determine $\mathrm{RU}_{\max }$ and $K_{\mathrm{D}}$ from the Langmuir equation for the STI1-PrP complex) regressions (Balducci et al., 2010).

A $\beta O$ binding to cells. HEK293T cells were transfected with $\mathrm{pH}-$ sensitive GFP-PrP ${ }^{\mathrm{C}}$ vector ( $\mathrm{pHFP}-\mathrm{PrP}^{\mathrm{C}}$ ) using a modified calcium phosphate method as described previously (Caetano et al., 2011). pHFP$\operatorname{PrP}^{\mathrm{C}}$ was generated on the basis of pEGFP-PrP ${ }^{\mathrm{C}}$ vector (Lee et al., 2001) with GFP nucleotide sequence exchanged for that of pHFP (pHluorin; Miesenbock et al., 1998). Fluorescent A $\beta O$ s were prepared from HiLyte Fluor 555-tagged $\mathrm{A} \beta_{1-42}$ (Anaspec) following the procedure described above. Three hundred nanomolar HiLyte Fluor 555-A $\beta$ Os alone or mixed with $500 \mathrm{~nm} \mathrm{STI1}$ or $1000 \mathrm{~nm}$ TPR2A were added to cultures for 15 min, after which cells were washed with Krebs-Ringer-HEPES (KRH) buffer (in mM: 50 HEPES, $115 \mathrm{NaCl}, 5.9 \mathrm{KCl}, 1 \mathrm{MgCl}_{2}, 2 \mathrm{CaCl}_{2}$, and 10 glucose, $\mathrm{pH} 7.4$ ) and immediately imaged on a LSM510 confocal microscope (Carl Zeiss) equipped with a $63 \times / 1.4$ numerical aperture (NA) oil-immersion objective. Data were collected from at least eight images taken for each treatment in three independent experiments. Bound HiLyte Fluor 555-A $\beta \mathrm{O}$ was quantified for at least 20 cells for each experimental condition as mean fluorescence per cell area and normalized to nontransfected cells using NIH ImageJ software. 
Primary cultures of hippocampal neurons from E17 mouse embryos were obtained as described previously (Beraldo et al., 2013). Neuronal cultures hereafter were derived from embryos of either sex. Cultures were maintained on poly-lysine-coated coverslips in Neurobasal medium with 2\% B-27 supplement (Invitrogen). On day 4, cytosine arabinoside ( $2 \mu \mathrm{M}$; Sigma) was added to prevent astrocyte growth. Half of the culture medium was changed every $2-3$ days. On day 15 , neurons were treated for 15 min with $200 \mathrm{~nm} \mathrm{~A} \beta \mathrm{O}$ alone or mixed with $500 \mathrm{~nm}$ STI1, washed with KRH buffer (in mM: $125 \mathrm{NaCl}, 5 \mathrm{KCl}, 5 \mathrm{HEPES}, 2.6 \mathrm{MgSO}_{4}$, and 10 glucose, $\mathrm{pH}$ 7.2). For $\gamma$-tubulin and $\mathrm{A} \beta \mathrm{O}$ immunostaining, cells were fixed with $4 \%$ paraformaldehyde for $20 \mathrm{~min}$, permeabilized with $0.5 \%$ Triton X-100 in PBS for 5 min, and blocked with 5\% BSA (Sigma) in PBS for $1 \mathrm{~h}$. After that, coverslips were incubated with anti- $\gamma$-tubulin (1:500; Abcam) and 6E10 (against amyloid- $\beta$ 1-16 epitope; 1:350; Covance) antibodies overnight at $4^{\circ} \mathrm{C}$, followed by secondary Alexa Fluor-488 (for $\gamma$-tubulin) and Alexa Fluor-633 (for $\mathrm{A} \beta \mathrm{O}$ ) antibodies (Invitrogen) for $1 \mathrm{~h}$ at $4^{\circ} \mathrm{C}$. For colocalization analysis, the PrP antibody $8 \mathrm{H} 4$ (epitope 145-180; Abcam) and 6E10 antibodies were labeled with Alexa Fluor-488 and Alexa Fluor-633, respectively, using Zenon Mouse Labeling Kit (Invitrogen). Briefly, $1 \mu \mathrm{g}$ of each primary antibody was incubated at room temperature for $5 \mathrm{~min}$ with $5 \mu \mathrm{l}$ of the corresponding Zenon coupling reagent, after which the reaction was stopped by 5 min incubation with the blocking reagent. Labeled antibodies were diluted immediately in KRH buffer (1:350 for both antibodies), added to neurons treated with $\mathrm{A} \beta \mathrm{O}, \mathrm{A} \beta \mathrm{O} / \mathrm{STI} 1$, or vehicle, as described above, and incubated for 30 $\min$ at $37^{\circ} \mathrm{C}$. Subsequently, cultures were washed with $\mathrm{KRH}$ buffer and imaged on an LSM510 confocal microscope equipped with a $63 \times / 1.4 \mathrm{NA}$ oil-immersion objective or a SP5 II confocal microscope (Leica) equipped with a $63 \times / 1.47 \mathrm{NA}$ oil-immersion objective. $\mathrm{A} \beta \mathrm{O}$, $\gamma$-tubulin, and $\mathrm{PrP}^{\mathrm{C}}$ were quantified in at least three independent experiments. At least five $Z$-stack images were taken randomly from each coverslip representing a single treatment of neurons derived from a single embryo, and the corresponding fluorescence was integrated using NIH ImageJ software. Neurites from at least 20 cells were analyzed with cell bodies excluded from the quantification. $\mathrm{A} \beta \mathrm{O}-\mathrm{PrP}^{\mathrm{C}}$ colocalization was determined as percentage of $\mathrm{A} \beta \mathrm{O}$ fluorescence volume colocalized with $\operatorname{PrP}^{\mathrm{C}}$ fluorescence using the NIH ImageJ colocalization plug-in.

Expression of synaptophysin. For these experiments, primary cultured hippocampal neurons were obtained as indicated previously (Roffé et al., 2013). Cytosine $\beta$-D-arabinofuranoside at $1 \mu \mathrm{m}$ was added on day 2 , and cultures were maintained with no media replacement. On day 20, cells that were preincubated with or without $100 \mathrm{nM}$ STI1 for $30 \mathrm{~min}$ and were treated with $500 \mathrm{~nm} \mathrm{~A} \beta \mathrm{O}$ for 1 or $4 \mathrm{~h}$ unless otherwise indicated. For Western blots, cells were lysed in RIPA buffer ( 50 mm Tris-Cl, pH 7.4, 150 mM NaCl, $1 \%$ NP-40, 0.5\% sodium deoxycholate, and $0.1 \%$ SDS) and analyzed by SDS-PAGE, followed by transfer to PVDF membrane and blotting with anti-synaptophysin (1:10,000; Santa Cruz Biotechnologies) and anti-GAPDH (1:1000; Sigma) antibodies. For immunofluorescence, cells were fixed with $4 \%$ paraformaldehyde for $20 \mathrm{~min}$, permeabilized with $0.2 \%$ Triton X-100 in PBS for 5 min, and blocked with 5\% BSA (Sigma) in PBS for $1 \mathrm{~h}$. Anti-synaptophysin (1:100; Santa Cruz Biotechnologies) diluted in $1 \%$ BSA in PBS was added for $1 \mathrm{~h}$, followed by anti-mouse Alexa Fluor-488 (1:1000; Invitrogen) for $1 \mathrm{~h}$. Twenty images were analyzed per experiment with the NIH ImageJ histogram tool in at least three independent experiments for each experimental treatment, using a Nikon TE2000 microscope in epifluorescence mode. Images taken from cells labeled with secondary antibody only were used to set the threshold for the experiment. Cell bodies were excluded from the analysis.

Electrophysiology in hippocampal tissue slices. Field EPSPs (fEPSPs) were recorded from hippocampal slices derived from wild-type mice that were between 21- and $30 \mathrm{~d}$-old as described previously (Martyn et al., 2012). Slices were pretreated for $15-30 \mathrm{~min}$ with or without 0.5 or $1 \mu \mathrm{M}$ STI1, followed by $30-60$ min treatment with vehicle or $1 \mu \mathrm{M} A \beta O$. No difference was observed between these two time points and protein concentrations used, and, therefore, the results of these experiments were pooled together.

Cell death and viability assays for $A \beta O$. Neuronal cultures $\left(1 \times 10^{5}\right.$ cells per $16 \mathrm{~mm}$ dish) were prepared as described previously (Beraldo et al., 2013). On day 11, neurons were treated with different proteins or peptides for $48 \mathrm{~h}$. Cell death was evaluated using the LIVE/DEAD Viability/Cytotoxicity Kit for mammalian cells (Invitrogen) as per the instructions of the manufacturer. Eight images from random fields containing at least 300 cells were taken for each experimental treatment of neurons prepared from at least five embryos on an LSM-510 confocal microscope equipped with $10 \times / 0.45 \mathrm{NA}$ objective and appropriate filters. Live (calcein-stained, green channel) and dead (ethidium-stained, red channel) cell counting was done using NIH ImageJ Cell Counter plug-in and calculated as percentage of dead cells [number dead cells/ (number of dead cells + viable cells) $\times 100$ ]. For the lactate dehydrogenase $(\mathrm{LDH})$ release assay, neuronal cultures were prepared in the same way but using phenol red-free medium. LDH release in cultured media was analyzed with LDH Activity Assay kit (Sigma) following the instructions of the manufacturer. For this, cultured media ( $400 \mu \mathrm{l}$ in a $16 \mathrm{~mm}$ dish) were concentrated to $100 \mu$ using Nanosep 10K centrifugal devices (Pall Life Sciences) and mixed with $200 \mu$ l of LDH substrate mix. After 30 min incubation, $\mathrm{LDH}$ activity was measured by $\mathrm{OD}_{450}$ on an iMark Microplate Absorbance Reader (Bio-Rad) and normalized to total protein concentration in the samples.

Cell death and viability assay for staurosporine. Neuronal cultures $\left(1 \times 10^{5}\right.$ cells per $16 \mathrm{~mm}$ dish) from wild-type or $\alpha 7 n A C h R^{-/-}$mice were prepared as described above. Primary hippocampal neurons were treated with staurosporine $(50 \mathrm{nM})$ in the presence or absence of $1 \mu \mathrm{M}$ STI1 for $16 \mathrm{~h}$ as described previously (Beraldo et al., 2010). The cell death assay was performed using LIVE/DEAD Viability/Cytotoxicity Kit as described above. The 3-(4,5-dimethylthiazol-2-yl)-2,5diphenyltetrazolium bromide (MTT) reduction assay (Sigma) was conducted according to the protocol of the manufacturer. MTT stock solution $(5 \mathrm{mg} / \mathrm{ml})$ was added to hippocampal neurons as $1 / 10$ of the culture medium volume and incubated for $4 \mathrm{~h}$. After that, the medium was removed, and cells were solubilized with isopropanol/0.1 N $\mathrm{HCl}$, after which absorbance of reduced dye was measured at $570 \mathrm{~nm}$ with background subtraction at $650 \mathrm{~nm}$.

Calcium signaling. Primary hippocampal neurons were obtained as described for experiments with $\mathrm{A} \beta \mathrm{O}$ binding, and calcium imaging was performed as described previously (Beraldo et al., 2010), by loading neurons with either $10 \mu \mathrm{M}$ fura- $2 \mathrm{AM}$ for $40 \mathrm{~min}$ or $5 \mu \mathrm{M}$ Fluo- $4 \mathrm{AM}$ (Invitrogen) for $30 \mathrm{~min}$ at $37^{\circ} \mathrm{C}$ in Neurobasal medium supplemented with 1 $\mathrm{mM} \mathrm{CaCl}_{2}$. For fura-2 AM experiments, data acquisition was performed using a DMI6000 B microscope (Leica) equipped with a $40 \times / 0.75 \mathrm{NA}$ dry objective and $340 \mathrm{~nm} / 380 \mathrm{~nm}$ (excitation) and $510 \mathrm{~nm}$ (emission) filters. Fluorescence ratio (340/380) was normalized using Leica AF6000 software. For Fluo-4 AM, data acquisition was performed on an LSM510 confocal microscope with excitation at $488 \mathrm{~nm}$ and emission at 505$530 \mathrm{~nm}$. Fluorescence was normalized as $\mathrm{F}_{1} / \mathrm{F}_{0}$ (in which $\mathrm{F}_{1}$ is maximal fluorescence and $\mathrm{F}_{0}$ is basal fluorescence). For each experimental condition, at least three different neuronal cultures from independent pups were used, and 30-40 cells were analyzed.

Human postmortem brain tissue. Parietal cortical tissues from age- and sex-matched controls ( $n=6,3$ females and 3 males) and AD-affected individuals ( $n=6,3$ females and 3 males) were provided by the Institute for Brain Aging and Dementia Tissue Repository/University of California, Irvine. AD diagnosis was confirmed by pathological and clinical criteria (McKhann et al., 1984; Khachaturian, 1985; Michalski and Fahnestock, 2003). Cortical samples were homogenized in RIPA buffer supplemented with protease inhibitor cocktail III (Calbiochem). STI1 levels were analyzed by SDS-PAGE, followed by Western blot analysis with anti-recombinant mouse STI1 antibody raised in rabbits (Zanata et al., 2002; Beraldo et al., 2013; purified IgG, $0.2 \mu \mathrm{g} / \mathrm{ml}$, generated by Bethyl Laboratories) using $\beta$-actin levels as a control.

Mouse brain tissue. Cortical tissues from APPswe/PS1dE9 or wild-type control male mice were collected and homogenized in RIPA buffer as described above. STI1 levels were analyzed by SDS-PAGE, followed by Western blot analysis with rabbit anti-STI1 antibody (Zanata et al., 2002; Beraldo et al., 2013) using $\beta$-actin levels as a control. 

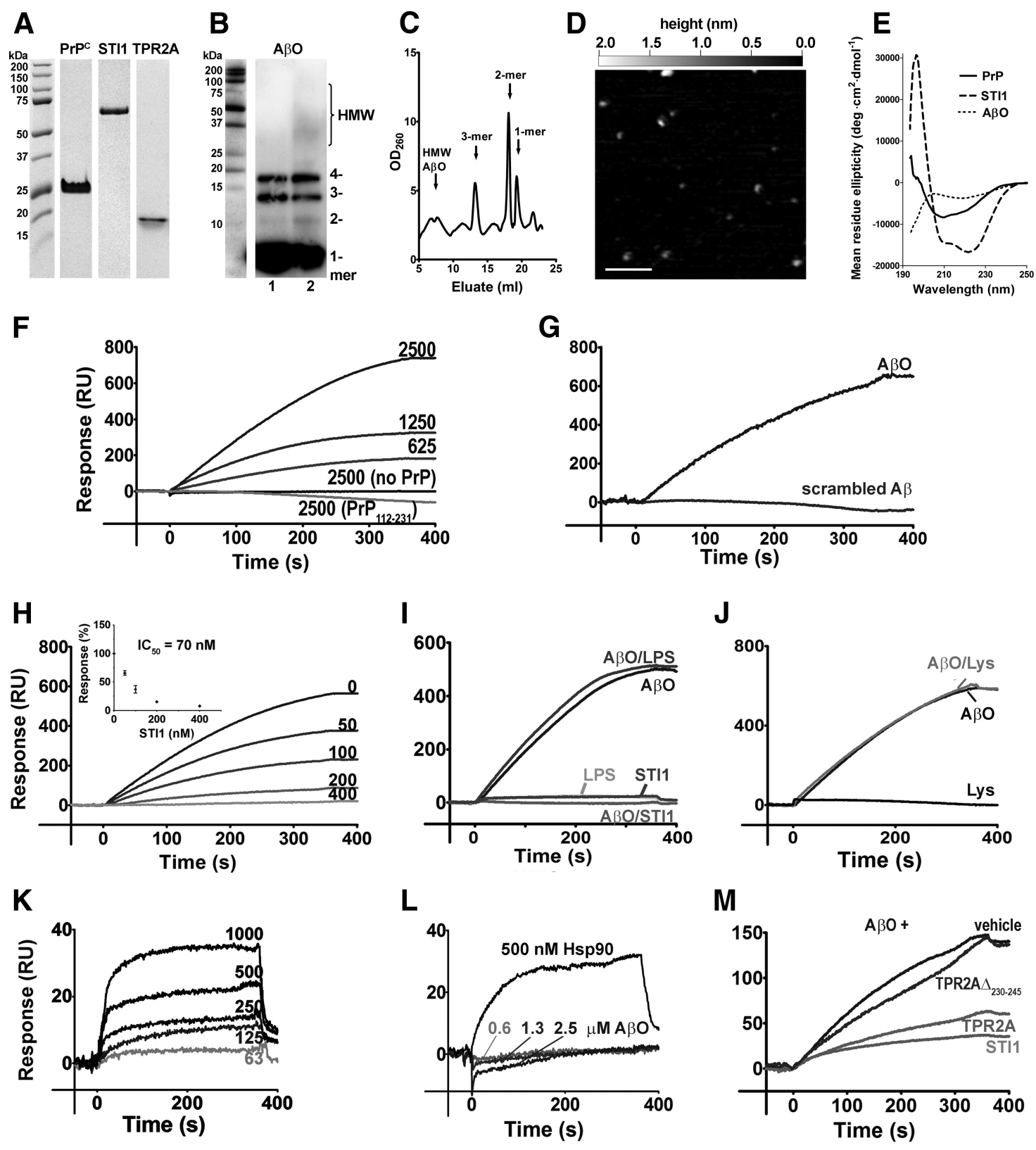

Figure 1. SPR studies of $A \beta 0$ binding to PrP. $A-E$, Characterization of protein and peptide preparations performed as described in Materials and Methods. $A$, SDS-PAGE analysis of recombinant proteins. $\boldsymbol{B}$, Western blot of $A \beta 0$ preparation with 6 E 10 antibody. Lane 1, Freshly prepared $A \beta 0$ s; lane $2,1 \mu \mathrm{m} \mathrm{A} \beta 0$ s after $48 \mathrm{~h}$ incubation in Neurobasal medium $/ 2 \%$ B-27 at $37^{\circ} \mathrm{C}$. C, Size-exchange chromatogram of $A \beta 0$ s; peaks for $A \beta_{1-42}$ monomers, dimers, and trimers and HMW aggregates are shown by arrows. $D, A$ representative AFM image of $A \beta 0$ preparations showing monomers $(\sim 0.3 \mathrm{~nm}$ high), dimers/trimers/tetramers ( $0.6-1.0 \mathrm{~nm}$ high), and a few HMW aggregates ( $>1 \mathrm{~nm}$ high). Scale bar, $100 \mathrm{~nm}$. $\boldsymbol{E}$, CD spectra of recombinant proteins and A $\beta 0$ s. $\boldsymbol{F}-\boldsymbol{M}, \mathbf{S P R}$ kinetics. $\boldsymbol{F}$, Binding of $A \beta 0$ s (nanomolar) to full-length PrP and to its N-terminal mutant PrP(112-231) on an NTA chip. G, Binding of scrambled A $\beta$ and A $\beta 0$ (both $2.5 \mu \mathrm{M})$ to PrP. $\boldsymbol{H}$, Binding of A $\beta 0$ s (2.5 $\mu \mathrm{M}$ ) to PrP in the presence of increasing concentrations of STI1 (nanomolar). Inset shows an inhibition curve for A $\beta 0$ binding to PrP obtained in multiple experiments (errors are smaller than symbols). $\boldsymbol{I}$, Similar to $\boldsymbol{H}$, but experiments were done in the presence of $0.2 \mathrm{EU}$ E. coli endotoxin (amount detected in recombinant STI1). J, Similar to $H$, but experiments were done in the presence of $500 \mathrm{~nm}$ lysozyme. $\boldsymbol{K}$, Binding of STI1 (nanomolar) to PrP immobilized on a CM5 chip. L, Binding of A $\beta 0$ s and Hsp90 to STI1 immobilized on a CM5 chip. M, Effects of TPR2A (1 $\mu \mathrm{M}$ ) and TPR2A $\Delta_{230-245}(1 \mu \mathrm{M})$ on A $\beta 0(2.5 \mu \mathrm{M})$ binding to PrP. SPR data are representative of at least three independent experiments.

\section{Results}

STI1 prevents A $\beta O$ binding to $\operatorname{PrP}^{\mathrm{C}}$

$\mathrm{A} \beta \mathrm{O}$ s and STI1 bind to adjacent regions of $\mathrm{PrP}^{\mathrm{C}}$, to residues 95-105 (Laurén et al., 2009) and 113-128, respectively (Zanata et al., 2002). To determine whether binding of these two $\operatorname{PrP}^{\mathrm{C}}$ ligands can occur simultaneously or whether they are mutually exclusive, we used SPR. We optimized standard procedures to obtain highly pure recombinant proteins ( $>95 \%$ according to SDS-PAGE analysis; Fig. $1 A$ ) and to produce well defined $\mathrm{A} \beta \mathrm{Os}$ with substantial presence of low-order oligomers (Townsend et al., 2006; Hung et al., 2008; Larson et al., 2012; Figueiredo et al., 2013). Western blot analysis of $A \beta O$ preparations showed $5-10 \%$ low-molecular-weight oligomers (2-, 3-, 4-mers) along with small amounts of higher-molecular-weight (HMW) components but no fibrils (Fig. 1B). Importantly, the size-exclusion chromatography profile of these oligomers was similar to that of $\mathrm{AD}$ brain-derived amyloid- $\beta$ species (Larson et al., 2012) and contained peaks corresponding to monomers, dimers, and trimers, with small amounts of HMW A $\beta \mathrm{O}$ (Fig. $1 C$ ). AFM analysis confirmed the abundance of low-order oligomers in our $\mathrm{A} \beta \mathrm{O}$ prep- 
A

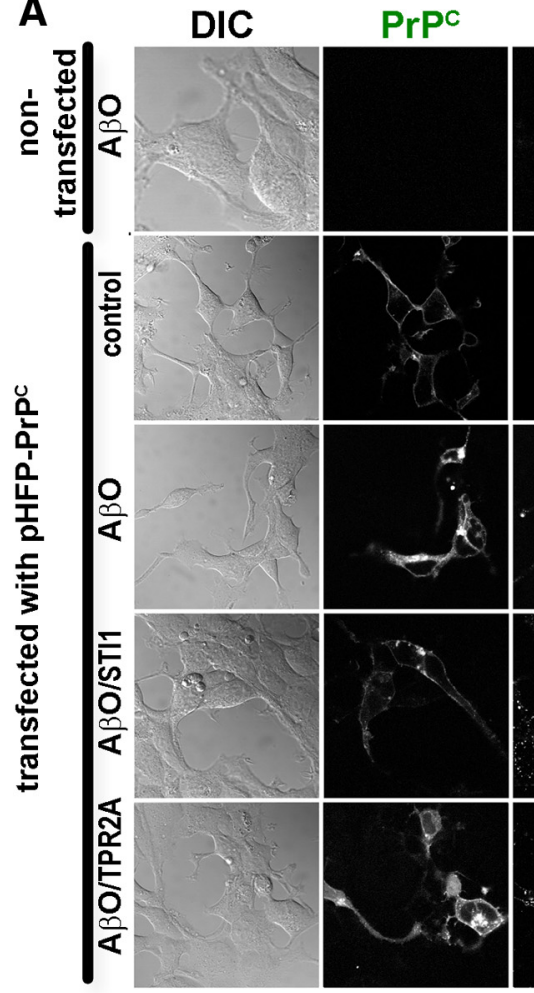

$\mathrm{A} \beta \mathrm{O}$

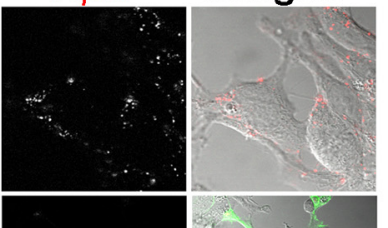

B DHEK293T DHEK293T/PHFPPRPC

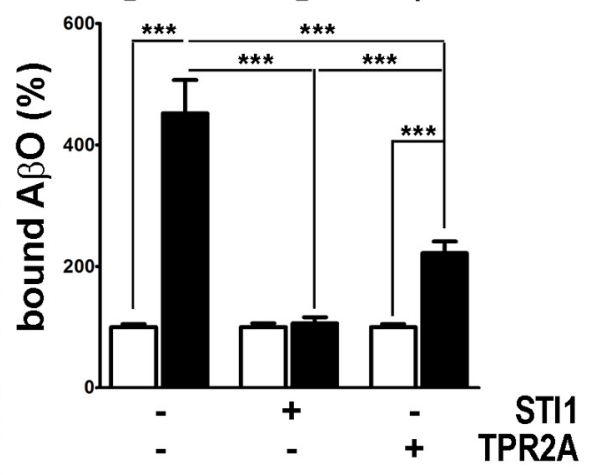

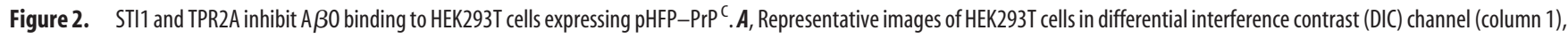
green channel (pHFP fluorescence, column 2), red channel (HiLyte Fluor 555-A 30 fluorescence, column 3), and merged (column 4). Row 1 shows nontransfected cells, and rows $2-5$ show cells

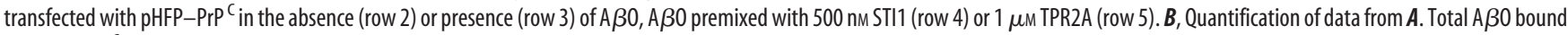
to pHFP-PrPC-transfected cells was normalized by cell size and by the amount of $A \beta 0$ bound to nontransfected cells. Data collected from at least 20 cells in three independent experiments were analyzed with one-way ANOVA with Tukey's post hoc test. ${ }^{* * *} p<0.001$.

aration, represented as $0.3-1 \mathrm{~nm}$ high round dots and a small amount of larger dots with their height $(>1 \mathrm{~nm})$ corresponding to HMW A $\beta \mathrm{O}$ (Fig. $1 D$ ). In addition, CD measurements demonstrated $\beta$-sheet structure in oligomer preparations and showed characteristic spectra for recombinant PrP (Ostapchenko et al., 2008) and STI1 (Romano et al., 2009; Fig. 1E).

Initial experiments demonstrated that $\mathrm{A} \beta \mathrm{O}$ s bind specifically to $\mathrm{PrP}$ in a dose-dependent manner (Fig. $1 F, G$ ). We used a simple bimolecular binding model to analyze SPR data and estimate kinetic constants of $\mathrm{A} \beta \mathrm{O}-\mathrm{PrP}$ binding. Considering that dimers and trimers, the main PrP-binding species in this preparation, represent $\sim 9 \%$ of the $\mathrm{A} \beta \mathrm{O}$ s in our preparation, we estimated $K_{\mathrm{D}}=15 \mathrm{nM}$, with $k_{\text {on }}=3500 \mathrm{M}^{-1} \mathrm{~s}^{-1}$ and $k_{\text {off }}=5.4 \times 10^{-5} \mathrm{~s}^{-1}$, which is consistent with previous studies (Balducci et al., 2010). Of note, approximating off-kinetics with exponential decay gave a high error estimate in the $k_{\text {off }}$ measurement $(\sim 50 \%)$, probably attributable to the fact that SPR signal noise and thermal drift magnitude were of the same order as the total SPR signal change during off-kinetics. Consequently, the calculated $K_{\mathrm{D}}$, as $k_{\text {off }} / k_{\text {on }}$, fell in the range of 7-30 nM. PrP lacking the $\mathrm{N}$-terminal region $[\operatorname{PrP}(112-231)]$ was unable to interact with $\mathrm{A} \beta \mathrm{O}$ s (Fig. $1 F)$. As a control, scrambled A $\beta$ did not bind to full-length $\operatorname{PrP}$ (Fig. $1 G$ ).

Recombinant STI1 impaired the binding of $A \beta O$ s to immobilized PrP with an $\mathrm{IC}_{50}$ of $\sim 70 \mathrm{~nm}$ (Fig. $1 \mathrm{H}$ ). To ensure absence of nonspecific effects, we determined the binding of $\mathrm{A} \beta \mathrm{O}$ s premixed with either lipopolysaccharide (amount equivalent to that present in $500 \mathrm{nM}$ recombinant STI1; Fig. 1I) or an irrelevant protein ( 500 nm lysozyme; Fig. $1 J$ ) to PrP. Neither of them altered $\mathrm{A} \beta \mathrm{O}$ binding to PrP. STI1 showed dose-dependent binding to
$\operatorname{PrP}\left(\right.$ Fig. $1 K$ ) with $K_{\mathrm{D}}=550 \pm 150 \mathrm{nM}, k_{\text {on }}=2.0 \pm 0.6 \times 10^{5}$ $\mathrm{M}^{-1} \mathrm{~s}^{-1}$, and $k_{\text {off }}=11.0 \pm 0.6 \times 10^{-2} \mathrm{~s}^{-1}$. The measured $K_{\mathrm{D}}$ value is in the same order of magnitude of values determined using different methodologies (Zanata et al., 2002; Romano et al., 2009). A $\beta$ Os did not interact directly with STI1, although STI1 was able to interact with Hsp90 as a positive control under the same conditions (Fig. 1L). The TPR2A domain of STI1 (containing $\operatorname{PrP}^{\mathrm{C}}$ binding motif amino acids $230-245$ ) decreased binding of $\mathrm{A} \beta \mathrm{O}$ to $\operatorname{PrP}\left(\mathrm{IC}_{50}\right.$ of $\left.\sim 300 \mathrm{nM}\right)$, whereas TPR2A $\Delta_{230-245}$, which lacks the PrP binding site, had no effect (Fig. $1 M$ ). Together, these results suggest that STI1 interferes with $\mathrm{A} \beta \mathrm{O}-\mathrm{PrP}$ binding by impairing $\mathrm{A} \beta \mathrm{O}$ binding to $\mathrm{PrP}$ and not because of a direct interaction between STI1 and $\mathrm{A} \beta \mathrm{O}$.

\section{STI1 prevents $\mathrm{A} \beta \mathrm{O}$ binding to cells expressing $\operatorname{PrP}^{\mathrm{C}}$}

To investigate whether STI1 affects $A \beta O$ binding to $\operatorname{PrP}^{C}$ on membranes of living cells, we initially used HEK293T cells. A $\beta O$ s bound only marginally to nontransfected cells, whereas HEK293T cells expressing pHFP-PrP ${ }^{\mathrm{C}}$ displayed abundant coating with $\mathrm{A} \beta \mathrm{Os}$ (Fig. $2 A, B$ ). In the presence of $500 \mathrm{~nm} \mathrm{STI} 1, \mathrm{~A} \beta \mathrm{O}$ binding to pHFP-PrP ${ }^{\mathrm{C}}$-transfected HEK293T cells was significantly decreased (Fig. $2 A, B)$. TPR2A (1 $\mu \mathrm{M})$ also decreased A $\beta O$ binding to cells (Fig. $2 A, B$ ).

In cultured hippocampal neurons, $\mathrm{A} \beta \mathrm{O}$ binding showed a punctate pattern mainly localized to neurites (Fig. $3 A, C$ ) as described previously (De Felice et al., 2007, 2009). As observed in HEK293T cells, A $\beta O$ binding to hippocampal neurons in culture was significantly decreased by STI1 when compared with cells treated with vehicle (Fig. $3 A-D$ ). Additionally, colocalization 
A
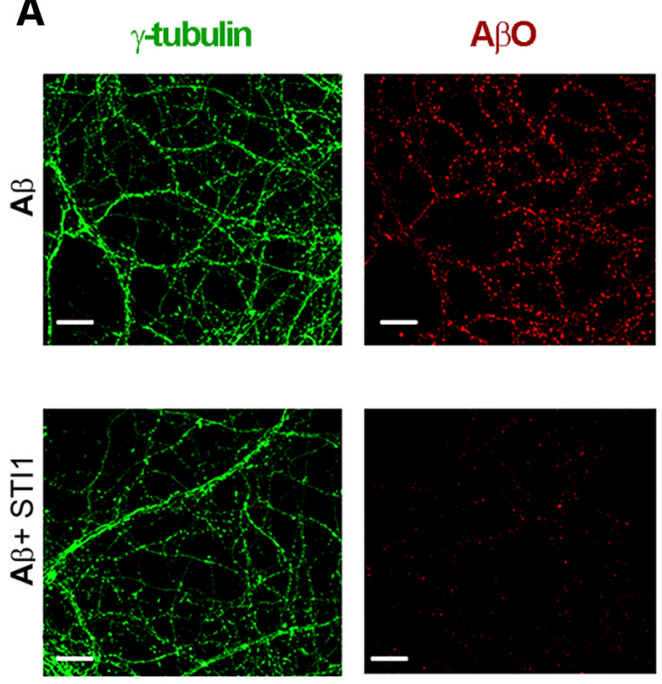

B

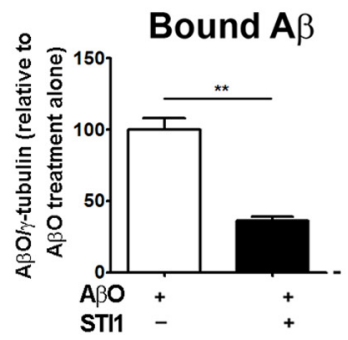

C
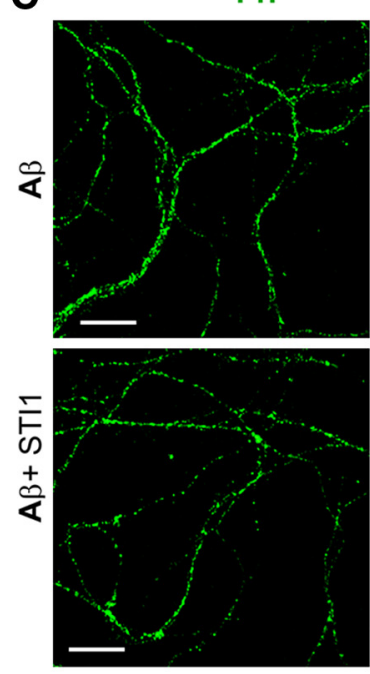

D

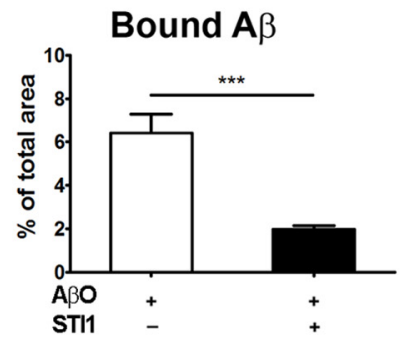

$\mathrm{A} \beta \mathrm{O}$
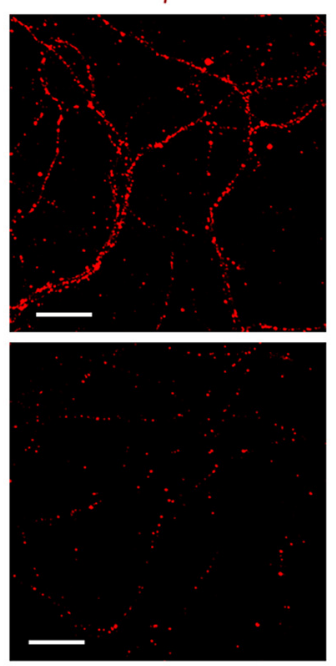

merged
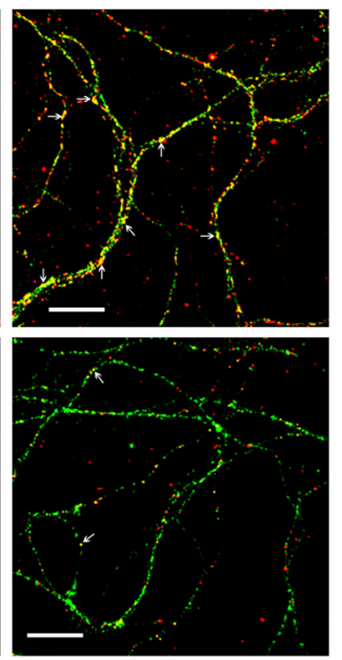

$\mathrm{A} \beta / \mathrm{PrP}^{\mathrm{C}}$ colocalization

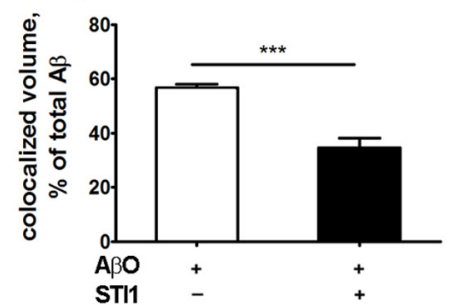

Figure 3. STI1 decreases $A \beta 0$ binding to $\operatorname{PrP}^{C}$ in hippocampal neuronal cultures. $A$, Representative images showing $\gamma$-tubulin (left column) and $A \beta 0$ (right column) staining of $15 \mathrm{~d}$ in vitro neurons treated with $A \beta 0$ (top row) or A $\beta 0 / S T I 1$ mix (bottom row) as described in Materials and Methods. $\boldsymbol{B}$, Quantification of $\boldsymbol{A}$. The amount of bound A $\beta 0$ s was normalized by $\gamma$-tubulin levels and presented relative to the treatment with $A \beta 0$ alone. C, Representative images showing PrP ${ }^{C}$ (left column), $A \beta 0$ (middle column), and merged (right column) staining of $15 \mathrm{~d}$ in vitro neurons treated with $\mathrm{A} \beta 0$ (top row) or A $\beta 0 /$ STI1 mix (bottom row) as described in Materials and Methods. White arrows indicate colocalized staining. D, Quantification of C. Bound A $\beta 0$ was quantified as percentage of image area. Colocalization with PrP ${ }^{C}$ was quantified as described in Materials and Methods. Scale bars, $10 \mu \mathrm{m}$. Data were collected from at least three independent experiments from neurites of at least 25 cells for each condition and analyzed with Student's $t$ test. ${ }^{* *} p<0.01,{ }^{* * *} p<0.001$.

analysis indicated that $\sim 50 \%$ of $\mathrm{A} \beta \mathrm{O}$ puncta were colocalized with $\operatorname{PrP}^{\mathrm{C}}$ (Fig. 3C,D). In the presence of STI1, colocalization between $\mathrm{A} \beta \mathrm{O}$ puncta and $\operatorname{PrP}^{\mathrm{C}}$ was significantly decreased in hippocampal neurons (Fig. $3 C, D$ ).

\section{STI1 prevents $\mathrm{A} \beta \mathrm{O}$-induced synaptic loss}

$\mathrm{A} \beta \mathrm{O}$ treatment of human brain tissue downregulates several genes involved in synaptic transmission, including synaptophysin (Sebollela et al., 2012). Moreover, A $\beta O$ s elicit $\operatorname{PrP}^{\mathrm{C}}$ dependent synaptic loss (Um et al., 2012). Treatment of hippocampal neurons in culture with $\mathrm{A} \beta \mathrm{O}$ s for 60 min led to a decrease in synaptophysin levels (Fig. $4 A-C$ ). In contrast, exposure of hippocampal neurons to STI1 (100 nM) increased the levels of synaptophysin (Fig. $4 B, C$ ). In the presence of STI1, the toxic effect of $\mathrm{A} \beta \mathrm{O}$ s on synaptophysin levels was prevented (Fig. $4 B, C)$. Importantly, neither $\mathrm{A} \beta \mathrm{O}$ or STI1 altered the levels of synaptophysin in hippocampal neurons cultured from $\operatorname{Prnp}^{-/-}$ embryos (Fig. 4D), indicating that these effects of A $\beta$ Os and STI1 depend on the presence of $\operatorname{PrP}^{\mathrm{C}}$.

\section{STI1 rescues A $\beta O$-induced inhibition of LTP in} hippocampal slices

It has been shown that impairment of LTP in hippocampal slices by $\mathrm{A} \beta \mathrm{O}$ s is mediated by $\operatorname{PrP}^{\mathrm{C}}$ (Laurén et al., 2009; Barry et al., 2011; Freir et al., 2011). Our results indicate that A $\beta O$ s, but not a preparation of scrambled A $\beta$, decreased LTP at Schaffer collater-
al-CA1 synapses (Fig. 5A, B). When slices were previously treated with STI1 $(0.5-1 \mu \mathrm{M})$, before being exposed to A $\beta O s$ s $(1 \mu \mathrm{M})$, no decrease in LTP was observed, suggesting that treatment with STI1 prevents $\mathrm{A} \beta \mathrm{O}$-induced LTP inhibition (Fig. $5 C, D$ ). Interleaved recordings from control slices treated with $\mathrm{A} \beta \mathrm{O}$ s alone confirmed the neurotoxic potency of $\mathrm{A} \beta \mathrm{O}$ in these experiments, whereas STI1 alone did not modify LTP (data not shown).

STI1 protects neurons against cellular injury induced by $\mathrm{A} \boldsymbol{\beta} O$ It has been shown that $\mathrm{A} \beta \mathrm{O}$ s cause neuronal cell death in $\operatorname{PrP}^{\mathrm{C}_{-}}$ dependent manner (Resenberger et al., 2011; Kudo et al., 2012). Corroborating this observation, we showed that wild-type but not $\operatorname{Prn} \mathrm{p}^{-/-}$cultured hippocampal neurons displayed decreased viability, measured using the LIVE/DEAD Viability/Cytotoxicity assay, when exposed to $1 \mu \mathrm{M} \mathrm{A} \beta \mathrm{O}$ for $48 \mathrm{~h}$ (Fig. $6 \mathrm{~A}$ ). Of note, incubation of $A \beta O$ s in culture medium did not produce measurable amounts of fibrils or prefibrillar aggregates (Fig. $1 B$ ), arguing that the observed toxicity is caused by low-molecular-weight A $\beta$ species. Next, we checked whether levels of endogenous STI1 could influence the neurotoxic effect of A $\beta O$ s. STI1 ${ }^{-/+}$neurons, shown previously to have $50 \%$ of wild-type STI1 protein levels (Beraldo et al., 2013), presented increased sensitivity to $A \beta O$ exposure (Fig. $6 B-D$ ). Treatment of cultured neurons with STI1 prevented the toxic effects of $\mathrm{A} \beta \mathrm{O}$ s in both STI1 mutant and wild-type neurons (Fig. 6B,D). Neither STI1 by itself nor scrambled $\mathrm{A} \beta$ had any effect on neuronal viability (Fig. $6 B, D$ ). More- 
over, treatment of cultured neurons with TPR2A, the $\operatorname{PrP}^{\mathrm{C}}$ binding domain of STI1, also decreased the toxicity of $\mathrm{A} \beta \mathrm{Os}$ (Fig. 6E). We also used LDH release as an indicator of cell death. Treatment with recombinant STI1 rescued neuronal death induced by $\mathrm{A} \beta \mathrm{O}$ s in both genotypes, confirming the results obtained with the LIVE/DEAD Viability/Cytotoxicity assay (Fig. 6F). In these experiments $\mathrm{A} \beta \mathrm{O}$ induced $\mathrm{LDH}$ release appeared higher in $S T I 1^{-/+}$neurons, but this difference failed to reach statistical significance (Fig. $6 F$ ). Together, our results indicate that STI1 decreases the binding of $\mathrm{A} \beta \mathrm{O}$ s to $\operatorname{PrP}^{\mathrm{C}}$ and prevents several toxic activities of $\mathrm{A} \beta \mathrm{Os}$ in hippocampal neurons.

STI1 induces intracellular $\mathrm{Ca}^{2+}$ increase and neuronal protection via $\alpha 7 \mathrm{nAChRs}$

We demonstrated previously that $\operatorname{PrP}^{\mathrm{C}}$ forms a biochemical and functional complex with $\alpha 7 \mathrm{nAChRs}$ and that signaling and neuronal protection by STI1 was blocked by $\alpha$-bungarotoxin, a selective $\alpha 7 \mathrm{nAChR}$-specific antagonist (Beraldo et al., 2010). $\mathrm{A} \beta_{1-42}$ has been shown to interact with $\alpha 7 \mathrm{nAChRs} \mathrm{(Wang} \mathrm{et} \mathrm{al.,} \mathrm{2000;}$ Magdesian et al., 2005; Snyder et al., 2005), which is thought to play an important role in AD (Hernandez and Dineley, 2012). To test whether neuroprotection by STI1 might involve $\alpha 7 \mathrm{nAChRs,} \mathrm{we} \mathrm{cul-}$ tured neurons from $\alpha 7 n A C h R^{-1-}$ mice and investigated the effect of STI1. We used neurons labeled with either fura-2 or Fluo-4 in independent experiments and found that $\mathrm{Ca}^{2+}$ increase induced by STI1 was abolished in $\alpha 7 n A C h R^{-1-}$ neurons (Fig. $7 A-$ $E)$. Moreover, the TPR2A peptide also increased intracellular $\mathrm{Ca}^{2+}$ in an $\alpha 7$ nAChR-dependent way.

Neuroprotection by STI1 against apoptosis induced by staurosporine (100 nM) was observed in wild-type neurons but not in $\alpha 7 n A C h R^{-1-}$ neurons, as determined by either the MTT reduction assay or the LIVE/DEAD Viability/Cytotoxicity assay (Fig. $7 F, G)$. Similarly to wild-type neurons, $\mathrm{A} \beta \mathrm{O}$ s induced $\sim 15-20 \%$ increase in cell death in $\alpha 7 n A C h R^{-/-}$neurons; surprisingly, however, addition of STI1 did not rescue those neurons from A $\beta O$-induced cell death (Fig. $7 H$ ). Of note, $\alpha 7 n A C h R^{-1-}$ neuronal cultures showed an increased background level of cell death [ $\sim 40$ vs $\sim 20 \%$ for wild-type neurons (Fig. $6 B$ )], suggesting that expression of $\alpha 7 \mathrm{nAChR}$ is important for cell viability in neuronal cultures.

\section{STI1 levels are increased in AD}

STI1 is part of the cellular stress response, and we showed recently that STI1 knock-out cells are less resilient to stress (Beraldo et al., 2013). Moreover, network analysis suggests that STIP1, the STI1 gene, may be a critical biological node for regulation of the unfolded protein response in AD cerebral cortex (Zhang et al., 2013). To determine whether STI1 levels change in AD, we fist performed analysis of the APPswe/PS1dE9 transgenic mouse model. These experiments revealed a $50 \%$ increase in cortical STI1 levels in 12-month-old APPswe/PS1dE9 but not in
B

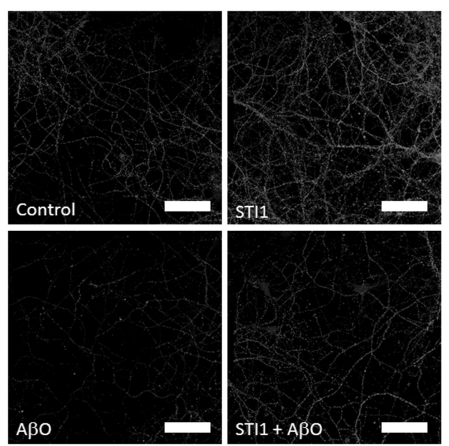

D

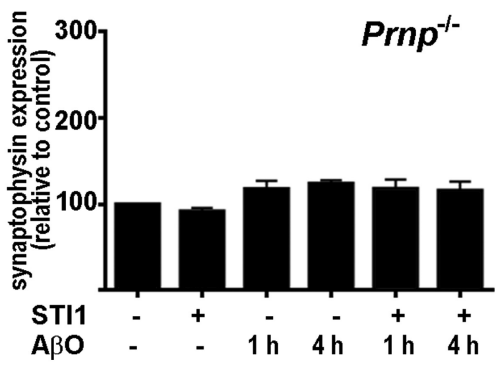

Figure 4. Synaptophysin levels in neurons treated with A $\beta 0$ s and STI1. $A$, Synaptophysin level in cultured hippocampal Synaptopsin (Syp) and GAPDH were performed. $\boldsymbol{B}$, Representative images for wild-type (Prnp ${ }^{+/+}$) neuronal cultures treated

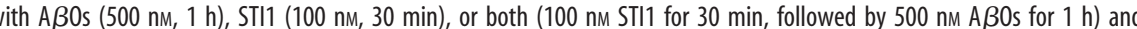

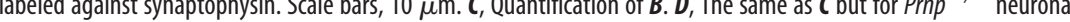
cultures. At least three independent experiments were done for each condition. Data were collected from 20 images containing neurites from at least 60 cells for each experiment and analyzed with one-way ANOVA with Tukey's post hoc test. ${ }^{*} p<0.05$.
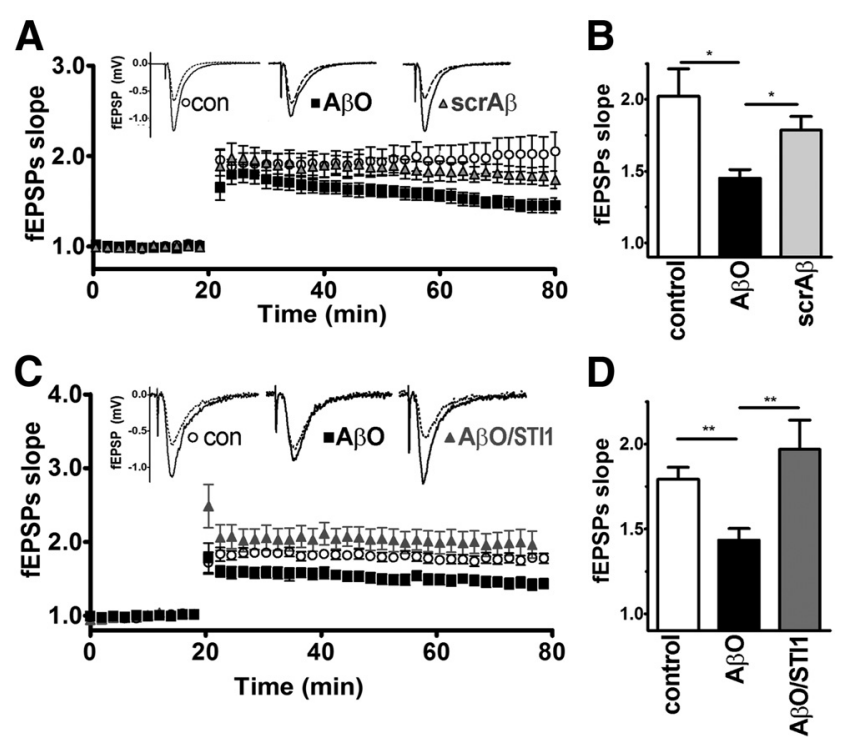

Figure 5. LTP measurements in hippocampal slices. $\boldsymbol{A}$, LTP in mouse hippocampal slices, treated with $A \beta 0$ or scrambled $A \beta$ as described in Materials and Methods. fEPSPs were recorded for 60 min after LTP induction. Inset shows typical pre-high-frequency stimulation (preHFS, dotted line) and post-HFS (solid lines) fEPSP traces. $B$, Bar graph summarizing averaged fEPSP slope values recorded at the endpoint (i.e., $80 \mathrm{~min}$ ) of $\boldsymbol{A}$. $\boldsymbol{C}$, The same as $\boldsymbol{A}$ but treated with $A \beta$ Os alone or with STI1. $D$, Bar graph summarizing averaged fEPSP slope values recorded at the endpoint (i.e., $80 \mathrm{~min}$ ) of $\boldsymbol{C}$. fEPSP slopes are presented as mean \pm SEM of at least five slices, relative to preinduction values, and analyzed by one-way ANOVA with Tukey's post hoc test. ${ }^{*} p<0.05,{ }^{* *} p<0.01$. 
A
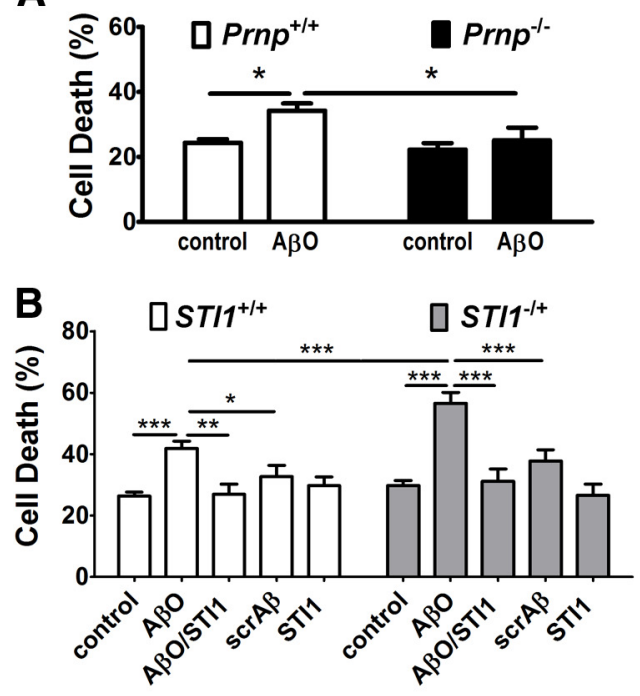

C

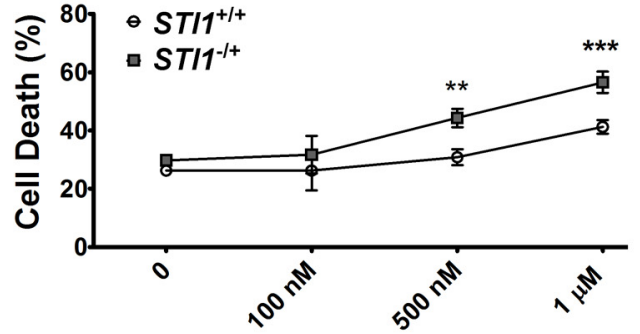

E

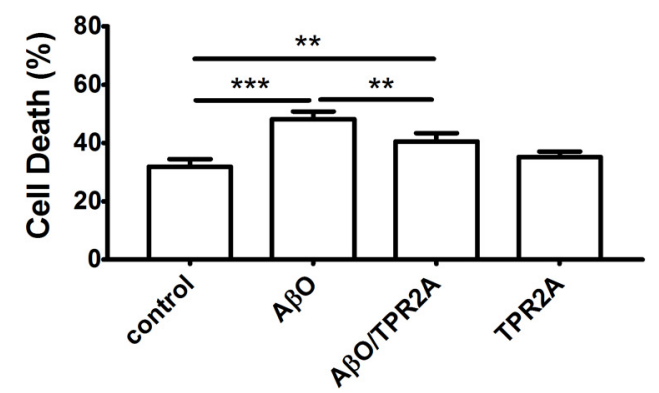

D
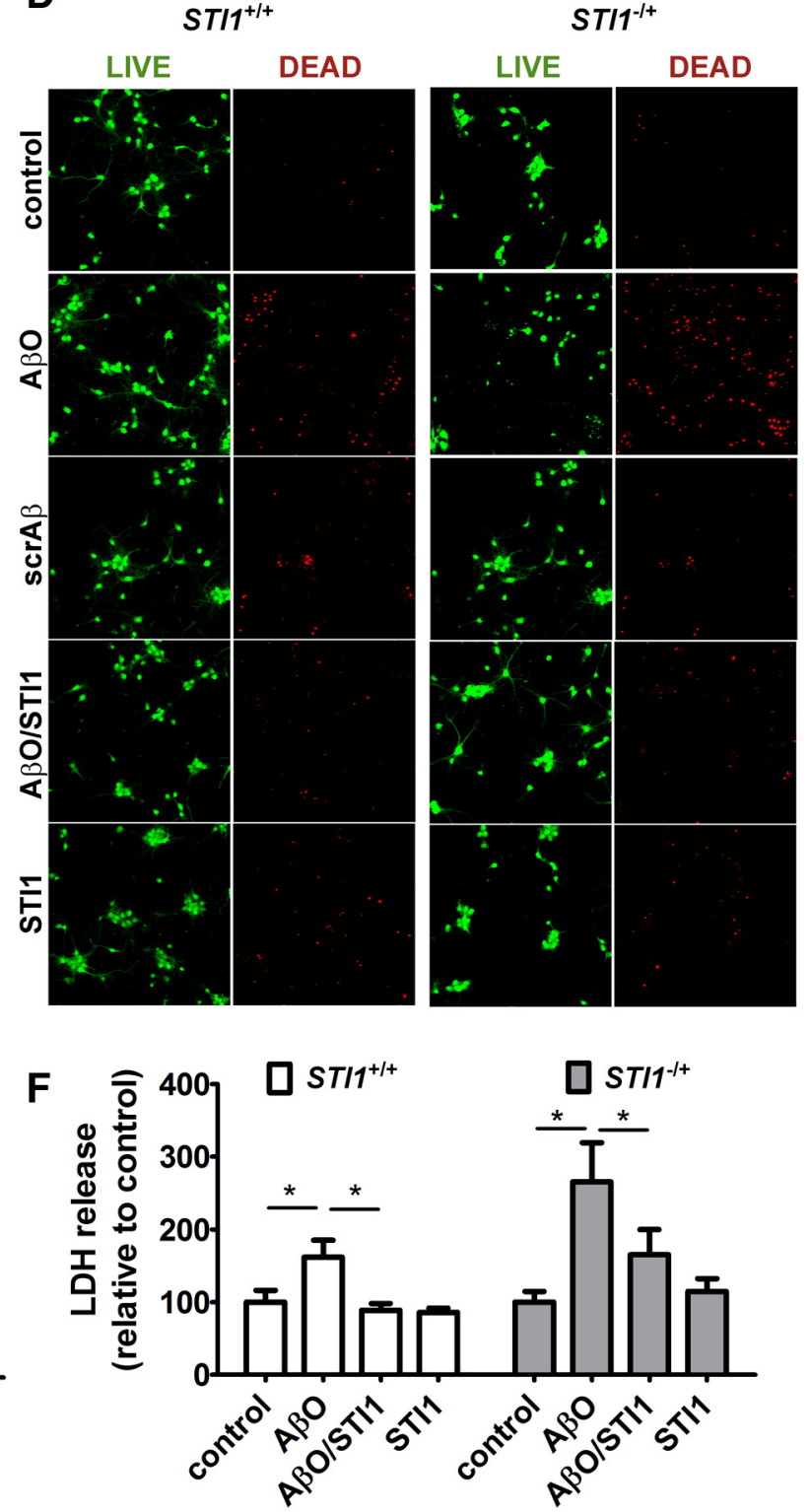

Figure 6. STI1 and TPR2A effect on A 30 -induced cell death in hippocampal neurons. $A-E$, LIVE/DEAD assay. $A$, Comparison of cell death in Prnp ${ }^{+/+}$and Prnp ${ }^{-/-}$neuronal cultures after $48 \mathrm{~h}$

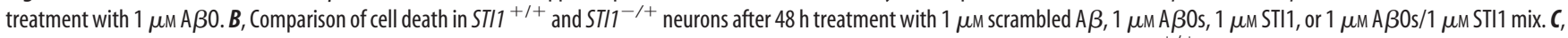
The same as in $\boldsymbol{B}$ but only for different concentrations of $A \beta 0$ s. $\boldsymbol{D}$, Representative images for $\boldsymbol{B}$. Left two columns, Live (green) and dead (red) ST/1 ${ }^{+/+}$neurons, nontreated (top row) or treated with $1 \mu \mathrm{mA} \beta 0 \mathrm{~s}, 1 \mu \mathrm{m} \mathrm{A} \beta 0 \mathrm{~s} / 1 \mu \mathrm{MSTI1}, 1 \mu \mathrm{mscrambled} \mathrm{A} \beta$, or $1 \mu \mathrm{MSTI1}$ (rows 2-5, respectively); right two columns, the same for STI1 ${ }^{-/+}$neurons. $E$, Comparison of cell death in wild-type neuronal cultures after $48 \mathrm{~h}$ treatment with $1 \mu \mathrm{m} \mathrm{A} \beta 0 \mathrm{~s}, 1 \mu \mathrm{m} \mathrm{TPR2A}$, or their mix. F, LDH release in ST/1 ${ }^{+/+}$and ST/1 ${ }^{-/+}$neuronal cultures after $48 \mathrm{~h}$ treatment with $1 \mu \mathrm{m} \mathrm{A} \beta 0 \mathrm{~s}, 1 \mu \mathrm{m} \mathrm{STI1}$, or their mix. At least five independent experiments were done for each genotype and condition. Experiments with different genotypes were analyzed by two-way ANOVA, followed by Bonferroni's post hoc test, and within the same genotype by one-way ANOVA, followed by Tukey's post hoc test. ${ }^{*} p<0.05,{ }^{* *} p<0.01,{ }^{* * *} p<0.001$.

9-month-old mice compared with wild-type controls (Fig. $8 A, B)$. Importantly, STI1 levels were also increased in AD brains when compared with age-matched controls (cohorts described in Table 1; Michalski and Fahnestock, 2003; Fig. 8C).

\section{Discussion}

Here we show that the $\operatorname{PrP}^{\mathrm{C}}$ ligand STI1 prevents deficits of synaptic plasticity and increased neuronal death induced by toxic $\mathrm{A} \beta \mathrm{O}$ species. Mechanistically, both interference with $\mathrm{A} \beta \mathrm{O}$ binding to neurons and $\alpha 7 \mathrm{nAChR}$ activation play a role in neuroprotection induced by STI1. Our data also demonstrate that STI1 levels are increased in $\mathrm{AD}$. Although the biological significance of this change in STI1 levels is not understood, it is possible that, without this compensatory response, toxic effects of $A \beta O$ s could be more prominent. These results open a novel avenue in $\mathrm{AD}$ research indicating that endogenous $\mathrm{PrP}^{\mathrm{C}}$ ligands can regulate toxicity by $\mathrm{A} \beta \mathrm{O}$.

\section{STI1 interferes with the $\mathrm{A} \beta \mathrm{O}-\mathrm{PrP}^{\mathrm{C}}$ interaction}

$A \beta O$ s have been shown to interact with several synaptic molecules (Ferreira and Klein, 2011), but its interaction with $\operatorname{PrP}^{\mathrm{C}}$ is one of the best characterized. Despite initial controversy (Balducci et al., 2010; Benilova and De Strooper, 2010; Kessels et al., 2010), a number of observations supported the notion that interaction of $A \beta O$ s with $\operatorname{PrP}^{C}$ activates toxic signaling in neurons (Laurén et al., 2009; Gimbel et al., 2010; Bate and Williams, 2011; 
Resenberger et al., 2011; Kudo et al., 2012; Um et al., 2012). We used well characterized synthetic $\mathrm{A} \beta \mathrm{O}$ s (Fig. 1) to mimic the effects of toxic $\mathrm{AD}$-related $\mathrm{A} \beta$ species. In our conditions, $\mathrm{A} \beta \mathrm{O}$ preparations typically contained $\sim 7 \%$ trimers and $\sim 2 \%$ dimers, in addition to tetramers and small levels of higher-order oligomers. Dimers and trimers are thought to be among the most toxic assemblies of $\mathrm{A} \beta$ (Townsend et al., 2006; Hung et al., 2008; Figueiredo et al., 2013) and have been shown to bind $\operatorname{PrP}^{\mathrm{C}}$ and to induce $\operatorname{PrP}^{\mathrm{C}}$-dependent toxic effects (Larson et al., 2012).

We confirmed the specificity of $\mathrm{A} \beta \mathrm{O}$ binding to purified PrP using SPR and also demonstrated that expression of $\operatorname{PrP}^{C}$ in cells increased $A \beta O$ binding substantially. These results are consistent with several other publications showing interaction between $\mathrm{A} \beta \mathrm{O}$ s from different sources and $\operatorname{PrP}^{\mathrm{C}}$ both in vitro and in vivo (Laurén et al., 2009; Balducci et al., 2010; Chen et al., 2010; Kessels et al., 2010; Larson et al., 2012). The $\mathrm{A} \beta \mathrm{O}-\mathrm{PrP}^{\mathrm{C}}$ complex is poorly understood at the molecular and structural levels, and its formation, based on SPR kinetic curves, is not likely to be a one-step process. It appears to start with a relatively slow binding phase with $k_{\text {on }}$ of just $3500 \mathrm{M}^{-1} \mathrm{~s}^{-1}$, but then the two proteins associate tightly $\left(k_{\text {off }}\right.$ of $\sim 5 \times 10^{-5}$ $\mathrm{s}^{-1}$ ), resulting in a high-affinity complex with $K_{\mathrm{D}}$ of $\sim 15 \mathrm{~nm}$. Therefore, it is reasonable to hypothesize that binding occurs in more than one step, and the initial lower-affinity interaction is followed by a rearrangement step leading to formation of a strong complex. Of note, the $K_{\mathrm{D}}$ for on-chip STI1 binding to $\operatorname{PrP}(550 \mathrm{nM})$ is higher than that observed for $\mathrm{A} \beta \mathrm{O}$ s, but its initial binding rate $\left(k_{\mathrm{on}}=2 \times 10^{5} \mathrm{M}^{-1}\right.$ $\mathrm{s}^{-1}$ ) is much faster, suggesting the possibility that STI1 could prevent the formation of this hypothetical initial low-affinity $\mathrm{A} \beta \mathrm{O}-$ $\mathrm{PrP}^{\mathrm{C}}$ complex. The molecular mechanism of this competition is probably related to the adjacent binding sites for STI 1 and $\mathrm{A} \beta \mathrm{O}$ on the $\operatorname{PrP}^{\mathrm{C}} \mathrm{N}$-terminal domain. Thus, binding of STI1 (or the TPR2A domain of STI1, which contains the motif responsible for STI1 binding to PrP) to amino acid residues 113-128 on PrP possibly makes adjacent regions sterically unavailable to other ligands. This could explain why TPR2A alone, a less bulky molecule compared with STI1, shows weaker inhibition of A $\beta O$ binding to PrP. Alternatively, conformational changes on PrP induced by STI1 (Romano et al., 2009) could also affect the interactions between PrP and $\mathrm{A} \beta \mathrm{O}$.

\section{STI1 prevents toxic effects of $A \beta O$ s}

Interaction of $\mathrm{A} \beta \mathrm{O}$ s with neurons leads to multiple neurotoxic effects, and although the underlying mechanisms have not been completely delineated, NMDA receptor-mediated excitotoxic-
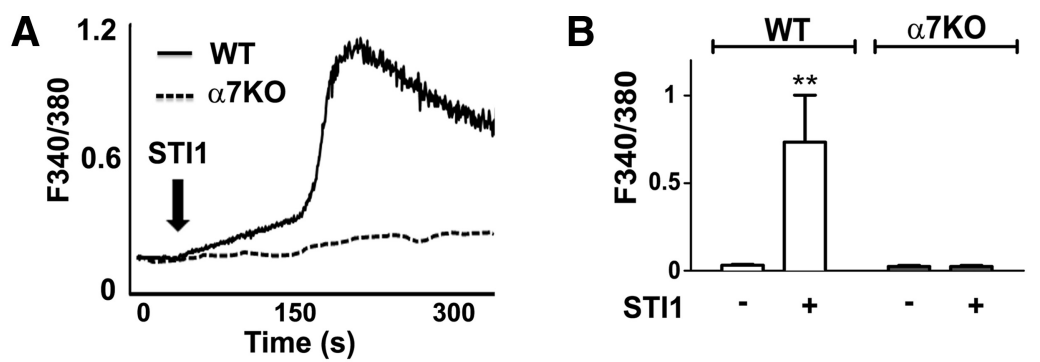

C

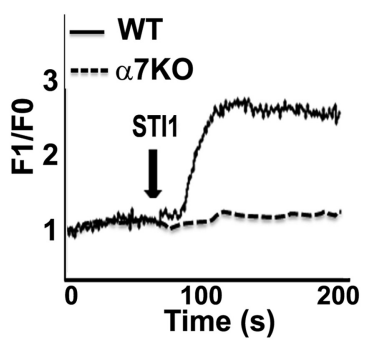

D
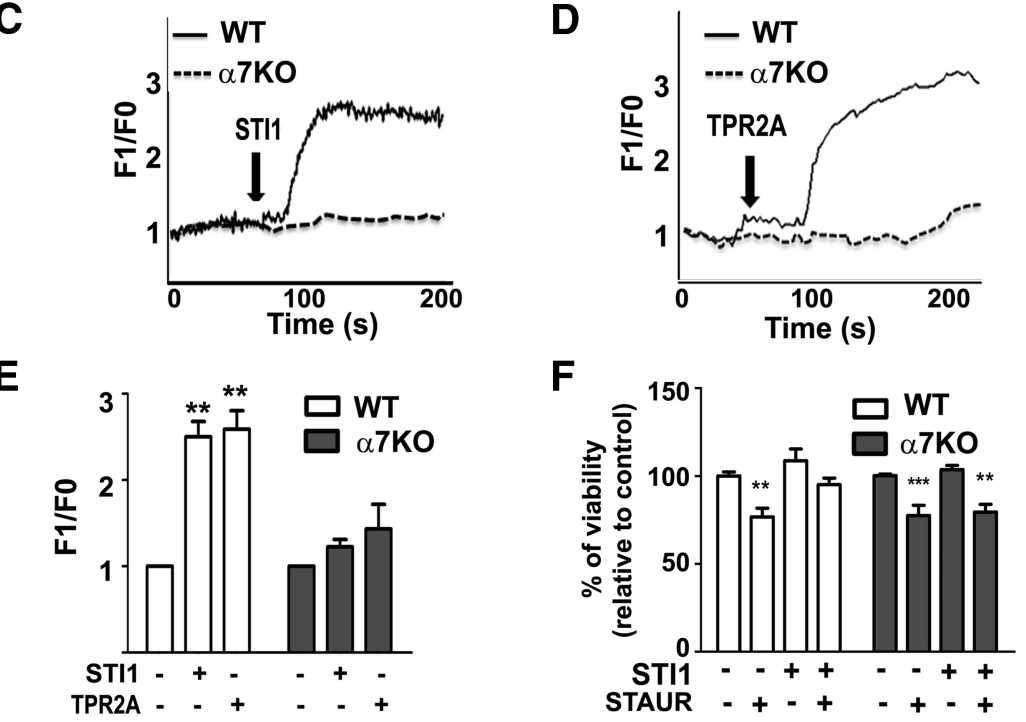

G

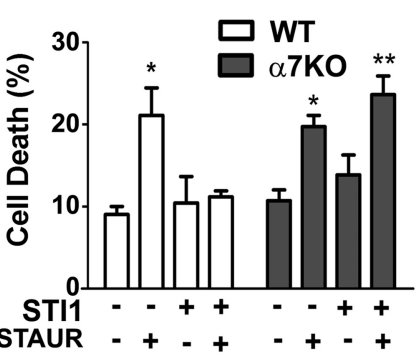

H

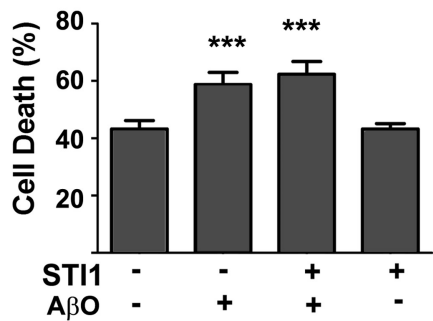

Figure 7. STI1 neuroprotection and effect on intracellular calcium in wild-type (WT) and $\alpha 7 n A C h R^{-1-}(\alpha 7 K 0)$ neurons. $\boldsymbol{A}$, Representative kinetics of intracellular calcium levels in wild-type and $\alpha 7 n A C h R^{-/-}$hippocampal neurons treated with STI1. Intracellular $\mathrm{Ca}^{2+}$ was measured by fura-2 AM fluorescence as described in Materials and Methods. $\boldsymbol{B}$, Calcium levels from $\boldsymbol{A}$ averaged from at least 30 cells. $C$, The same as $A$ but measured with Fluo-4 AM fluorescence as described in Materials and Methods. $\boldsymbol{D}$, The same as $\boldsymbol{C}$ but neurons were treated with TPR2A. $\boldsymbol{E}$, Calcium levels from $\boldsymbol{C}$ and $\boldsymbol{D}$ averaged from at least 30 cells. $\boldsymbol{F}$, MTT assay of cell viability in wild-type and $\alpha 7 n A C h R^{-/-}$neuronal cultures, treated for $16 \mathrm{~h}$ with $50 \mathrm{~nm}$ staurosporine, $1 \mu \mathrm{m} S T I 1$, or their mix, as described in Materials and Methods. $\boldsymbol{G}$, The same as in $\boldsymbol{F}$ but measured by LIVE/DEAD Viability/Cytotoxicity assay, as described in Materials and Methods. Data represent four independent experiments analyzed by two-way ANOVA with Bonferroni's post hoc test. ${ }^{*} p<0.01,{ }^{* *} p<0.001,{ }^{* * *} p<0.0001 . H$, Comparison of cell death in $\alpha 7 n A C h R^{-/-}$neuronal cultures after $48 \mathrm{~h}$ treatment with $1 \mu \mathrm{m} \mathrm{A} \beta 0,1 \mu \mathrm{m}$ STI1, or their mix, measured by LIVE/DEAD Viability/Cytotoxicity assay. Neuronal cultures were obtained from 13 independent embryos, and the data were analyzed by one-way ANOVA with Tukey's post hoc test. ${ }^{* * *} p<0.0001$.

ity and abnormal activation of Fyn kinase have been implicated (Larson et al., 2012; Um et al., 2012). Abnormal activation of NMDAR and Fyn kinase seem to connect toxic actions of $A \beta O s$ to altered Tau function (Ittner et al., 2010). $\operatorname{PrP}^{\mathrm{C}}$ seems to interact directly with NMDA receptors and to regulate their desensitization by providing a source of copper, which can be disrupted by increased $A \beta_{1-42}$ (You et al., 2012). In agreement with these toxic effects, $\mathrm{A} \beta \mathrm{O}$ s disrupt synaptic plasticity, including LTP, which has been shown to be an effect dependent on $\operatorname{PrP}^{\mathrm{C}}$ (Laurén et al., 2009; Barry et al., 2011; Freir et al., 2011). We found that, in neuronal cultures, $A \beta O$ s decreased the levels of the presynaptic marker synaptophysin, similar to findings in $\mathrm{A} \beta \mathrm{O}$-treated hu- 
A
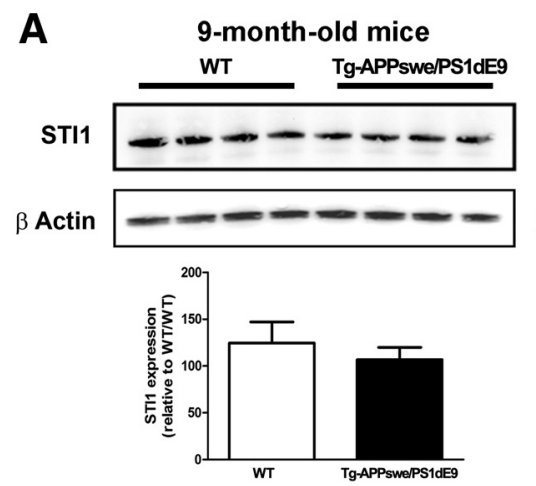

C

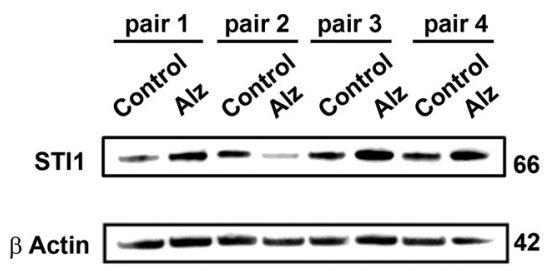

B

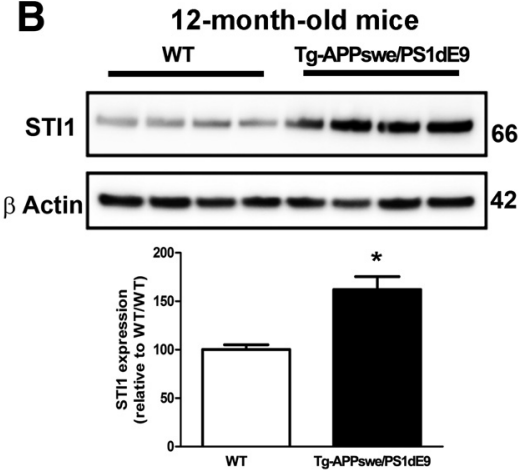

Human parietal cortex

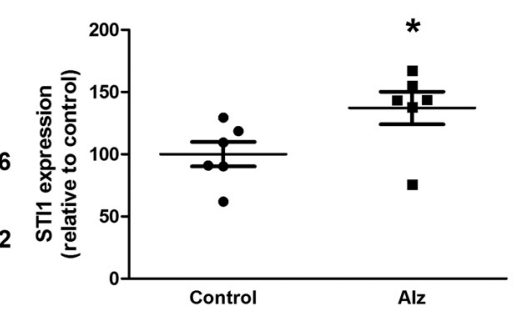

Figure 8. STI1 levels in APPswe/PS1dE9 mice and AD brains. A, Comparison of STI1 levels in 9-month-old APPswe/PS1dE9 and wild-type (WT) mice by Western blot. $\boldsymbol{B}$, Similar analysis for 12 -month-old mice. Data collected from at least six animals were normalized by actin levels and analyzed by Student's $t$ test. ${ }^{*} p<0.05$. C, Comparison of STI 1 levels in AD (Alz) and age-matched control brains. Data were collected from three male and three female AD brains and age-matched control brains, normalized by $\beta$-actin levels and analyzed by Student's $t$ test. ${ }^{*} p<0.05$.

We also showed that neurons haploinsufficient for STI1 are more sensitive to $\mathrm{A} \beta \mathrm{O}$-induced cell death, a result consistent with our recent findings that cells are less resilient in the absence of STI1 (Beraldo et al., 2013). Hence, the differential expression of STI1 in AD brains may have physiological significance. Interestingly, flies harboring an STI1 mutation showed increased toxicity in a model of tauopathy (Ambegaokar and Jackson, 2011), suggesting that STI1 may be a critical regulator of distinct pathological signatures in $\mathrm{AD}$. The increased neuronal death induced by $\mathrm{A} \beta \mathrm{O}$ s in STI1-mutant hippocampal neurons could be prevented by extracellular recombinant STI1. We showed previously that extracellular recombinant STI1 reproduces the effect of secreted STI1 (Caetano et al., 2008). Moreover, the TPR2A STI1 domain, which lacks cochaperone activity because it is unable to bind both Hsp90 and Hsp70 (Brinker et al., 2002), could also prevent $\mathrm{A} \beta \mathrm{O}$-mediated neuronal death, suggesting that the neuroprotective effects of STI1 may not be related to a cochaperone mechanism.

\section{Table 1. Human parietal cortex samples}

\begin{tabular}{llll}
\hline Diagnosis & Age & PMI & Sex \\
\hline Pair 1 & & & $\mathrm{F}$ \\
$\quad$ Control & 82 & 7.25 & \\
AD & 82 & 3.00 & $\mathrm{~F}$ \\
Pair 2 & & & \\
$\quad$ Control & 87 & 6.50 & $\mathrm{M}$ \\
AD & 88 & 4.25 & \\
Pair 3 & & & \\
$\quad$ Control & 64 & 4.50 & $\mathrm{M}$ \\
AD & 66 & 3.00 & $\mathrm{M}$ \\
Pair 4 & & & \\
Control & 78 & 6.00 & \\
AD & 79 & 2.75 & \\
Pair 5 & & & \\
$\quad$ Control & 80 & 7.00 & \\
AD & 80 & 2.75 & \\
Pair 6 & & 8.00 & \\
Control & 93 & 3.25 & \\
AD & 79 & 19 & \\
\hline
\end{tabular}

Samples were taken from control and AD postmortem brains with indicated postmortem interval (PMI, hours) and age and sex matched in pairs (except for pair 6) for Western blot analysis of STI1 levels.

man cortical slices (Sebollela et al., 2012). Conversely, STI1 increased immunoreactivity for synaptophysin, consistent with its known effect of increasing neuronal protein synthesis (Roffé et al., 2010). Additionally, STI1 was able to protect hippocampal neurons from the toxic effect of $A \beta O$ s on synaptophysin levels. Importantly, the effects of both STI1 and A $\beta$ Os on synaptophysin levels were lost in cultures from $\operatorname{PrP}^{\mathrm{C}}$-null mice, indicating that $\mathrm{PrP}^{\mathrm{C}}$ is involved in these signaling pathways. Moreover, STI1 prevented inhibition of LTP induced by A $\beta O$ s. These results suggest that increased extracellular levels of STI1, a $\operatorname{PrP}^{\mathrm{C}}$ ligand that is secreted by astrocytes (Beraldo et al., 2013; Hajj et al., 2013), can mitigate $\mathrm{A} \beta \mathrm{O}$-mediated synaptic toxicity.

\section{Mechanism for prevention of $\mathrm{A} \beta \mathrm{O}$-mediated toxicity}

Although STI1 decreases the binding of $\mathrm{A} \beta \mathrm{O}$ s to $\mathrm{PrP}^{\mathrm{C}}$ in vitro, it is also possible that the protein could regulate $\mathrm{A} \beta \mathrm{O}$-mediated toxicity by activating neuroprotective signaling pathways (Lopes et al., 2005; Caetano et al., 2008; Beraldo et al., 2010; Roffé et al., 2010). We found that STI1-mediated $\mathrm{Ca}^{2+}$ influx was abolished in neurons from $\alpha 7 \mathrm{nAChR}$-null mice and that STI1-mediated neuroprotection is impaired in these mutants. Importantly, prevention of $\mathrm{A} \beta \mathrm{O}$-induced neuronal death by STI1 was not observed in $\alpha 7 \mathrm{nAChR}$-null neurons. This result suggests that, in the presence of STI1, residual $\mathrm{A} \beta \mathrm{O}$ complexes with $\mathrm{PrP}^{\mathrm{C}}$ or other targets may still initiate toxic responses. Nonetheless, STI1 activation of the $\operatorname{PrP}^{\mathrm{C}} / \alpha 7 \mathrm{nAChR}$ pathway seems to prevent these effects. Together, these results argue that decrease of $\mathrm{A} \beta \mathrm{O}$ interaction with $\mathrm{PrP}^{\mathrm{C}}$ in addition to activation of $\alpha 7 \mathrm{nAChR}$-mediated neuroprotection pathways may participate in the effects of STI1.

Our work is consistent with previous studies showing neuroprotective roles of $\alpha 7 \mathrm{nAChR}$ in AD (Dineley et al., 2001; Hernandez et al., 2010; Shen et al., 2010). Indeed, A $\beta$ actions via $\alpha 7$ nAChRs may also affect hippocampal LTP (Gu and Yakel, 2011), and genetic depletion of $\alpha 7 \mathrm{nAChRs}$ in an early-stage AD mouse model exacerbated cognitive deficits and septohippocampal pathology (Hernandez et al., 2010). Interestingly, higher concentrations or chronic exposure to A $\beta \mathrm{O}$ appears to corrupt $\alpha 7 \mathrm{nAChR}$ function, which can be prevented by intervening small molecules (Wang et al., 2009, 2012) or by genetic depletion of $\alpha 7 \mathrm{nAChR}$ (Dziewczapolski et al., 2009). It remains to be determined whether biasing signaling via $\operatorname{PrP} / \alpha 7 \mathrm{nAChR}$ by further increasing STI1 levels could be used to prevent the toxic actions of $A \beta O$ s in vivo.

\section{Conclusion}

Our studies suggest the possibility that STI1 may influence toxic responses to $\mathrm{A} \beta$ oligomers in $\mathrm{AD}$. Increased levels of STI1 ob- 
served in $\mathrm{AD}$ brain may exert a protective role, although this obviously cannot prevent toxicity in advanced disease. It is possible that higher levels of STI1 are part of a compensatory response that may mitigate toxicity. Future experiments using tissue-specific elimination of STI1 may help to clarify this issue.

STI1 is a cochaperone known to interact with Hsp90 and Hsp70 to facilitate client transfer (Southworth and Agard, 2011). Our experiments in neurons support the importance of extracellular STI1 in protection against $\mathrm{A} \beta \mathrm{O}$ toxicity; however, we cannot completely exclude that intracellular STI1 may also participate in cellular resilience in this condition (Beraldo et al., 2013). Increased chaperone activity may also play a role in protection against prolonged $\mathrm{A} \beta \mathrm{O}$ exposure (Resenberger et al., 2012), which induces oxidative stress (De Felice et al., 2007) and mitochondrial damage in neurons (Paula-Lima et al., 2011), leading to increased load of misfolded proteins (Li et al., 2009). Interestingly, we showed recently that, after 9 months of age, APP/Ps1dE9 mice seem to present increased oxidative stress, revealed by increased $\operatorname{PrP}^{\mathrm{C}} \beta$ processing (Ostapchenko et al., 2013). Our present findings describe a novel neuroprotective role for the $\mathrm{PrP}^{\mathrm{C}}$ ligand STI1, which added to recent systems biology reports (Ambegaokar and Jackson, 2011; Zhang et al., 2013), implicates STI1 in distinct aspects of AD.

\section{References}

Ambegaokar SS, Jackson GR (2011) Functional genomic screen and network analysis reveal novel modifiers of tauopathy dissociated from tau phosphorylation. Hum Mol Genet 20:4947-4977. CrossRef Medline

Balducci C, Beeg M, Stravalaci M, Bastone A, Sclip A, Biasini E, Tapella L, Colombo L, Manzoni C, Borsello T, Chiesa R, Gobbi M, Salmona M, Forloni G (2010) Synthetic amyloid-beta oligomers impair long-term memory independently of cellular prion protein. Proc Natl Acad Sci U S A 107:2295-2300. CrossRef Medline

Barry AE, Klyubin I, Mc Donald JM, Mably AJ, Farrell MA, Scott M, Walsh DM, Rowan MJ (2011) Alzheimer's disease brain-derived amyloid- $\beta$ mediated inhibition of LTP in vivo is prevented by immunotargeting cellular prion protein. J Neurosci 31:7259-7263. CrossRef Medline

Bate C, Williams A (2011) Amyloid-beta-induced synapse damage is mediated via cross-linkage of cellular prion proteins. J Biol Chem 286:3795537963. CrossRef Medline

Benilova I, De Strooper B (2010) Prion protein in Alzheimer's pathogenesis: a hot and controversial issue. EMBO Mol Med 2:289-290. CrossRef Medline

Beraldo FH, Soares IN, Goncalves DF, Fan J, Thomas AA, Santos TG, Mohammad AH, Roffé M, Calder MD, Nikolova S, Hajj GN, Guimaraes AL, Massensini AR, Welch I, Betts DH, Gros R, Drangova M, Watson AJ, Bartha R, Prado VF, et al. (2013) Stress-inducible phosphoprotein 1 has unique cochaperone activity during development and regulates cellular response to ischemia via the prion protein. FASEB J 27:3594-3607. CrossRef Medline

Beraldo FH, Arantes CP, Santos TG, Queiroz NG, Young K, Rylett RJ, Markus RP, Prado MA, Martins VR (2010) Role of alpha7 nicotinic acetylcholine receptor in calcium signaling induced by prion protein interaction with stress-inducible protein 1. J Biol Chem 285:36542-36550. CrossRef Medline

Beraldo FH, Arantes CP, Santos TG, Machado CF, Roffe M, Hajj GN, Lee KS, Magalhães AC, Caetano FA, Mancini GL, Lopes MH, Américo TA, Magdesian MH, Ferguson SS, Linden R, Prado MA, Martins VR (2011) Metabotropic glutamate receptors transduce signals for neurite outgrowth after binding of the prion protein to laminin gammal chain. FASEB J 25:265-279. CrossRef Medline

Brinker A, Scheufler C, Von Der Mulbe F, Fleckenstein B, Herrmann C, Jung G, Moarefi I, Hartl FU (2002) Ligand discrimination by TPR domains. Relevance and selectivity of EEVD-recognition in Hsp70 x Hop x Hsp90 complexes. J Biol Chem 277:19265-19275. CrossRef Medline

Caetano FA, Lopes MH, Hajj GN, Machado CF, Pinto Arantes C, Magalhães AC, Vieira Mde P, Américo TA, Massensini AR, Priola SA, Vorberg I, Gomez MV, Linden R, Prado VF, Martins VR, Prado MA (2008) Endo- cytosis of prion protein is required for ERK1/2 signaling induced by stress-inducible protein 1. J Neurosci 28:6691-6702. CrossRef Medline

Caetano FA, Beraldo FH, Hajj GN, Guimaraes AL, Jürgensen S, WasilewskaSampaio AP, Hirata PH, Souza I, Machado CF, Wong DY, De Felice FG, Ferreira ST, Prado VF, Rylett RJ, Martins VR, Prado MA (2011) Amyloid-beta oligomers increase the localization of prion protein at the cell surface. J Neurochem 117:538-553. CrossRef Medline

Chen S, Yadav SP, Surewicz WK (2010) Interaction between human prion protein and amyloid-beta (Abeta) oligomers: role OF N-terminal residues. J Biol Chem 285:26377-26383. CrossRef Medline

Chiarini LB, Freitas AR, Zanata SM, Brentani RR, Martins VR, Linden R (2002) Cellular prion protein transduces neuroprotective signals. EMBO J 21:3317-3326. CrossRef Medline

Chung E, Ji Y, Sun Y, Kascsak RJ, Kascsak RB, Mehta PD, Strittmatter SM, Wisniewski T (2010) Anti-PrPC monoclonal antibody infusion as a novel treatment for cognitive deficits in an Alzheimer's disease model mouse. BMC Neurosci 11:130. CrossRef Medline

Decker H, Jürgensen S, Adrover MF, Brito-Moreira J, Bomfim TR, Klein WL, Epstein AL, De Felice FG, Jerusalinsky D, Ferreira ST (2010) N-methyl$\mathrm{D}$-aspartate receptors are required for synaptic targeting of Alzheimer's toxic amyloid-beta peptide oligomers. J Neurochem 115:1520-1529. CrossRef Medline

De Felice FG, Velasco PT, Lambert MP, Viola K, Fernandez SJ, Ferreira ST, Klein WL (2007) Abeta oligomers induce neuronal oxidative stress through an N-methyl-D-aspartate receptor-dependent mechanism that is blocked by the Alzheimer drug memantine. J Biol Chem 282:1159011601. CrossRef Medline

De Felice FG, Vieira MN, Bomfim TR, Decker H, Velasco PT, Lambert MP, Viola KL, Zhao WQ, Ferreira ST, Klein WL (2009) Protection of synapses against Alzheimer's-linked toxins: insulin signaling prevents the pathogenic binding of Abeta oligomers. Proc Natl Acad Sci U S A 106: 1971-1976. CrossRef Medline

Dineley KT, Westerman M, Bui D, Bell K, Ashe KH, Sweatt JD (2001) $\beta$-Amyloid activates the mitogen-activated protein kinase cascade via hippocampal $\alpha 7$ nicotinic acetylcholine receptors: in vitro and in vivo mechanisms related to Alzheimer's disease. J Neurosci 21:4125-4133. Medline

Dziewczapolski G, Glogowski CM, Masliah E, Heinemann SF (2009) Deletion of the $\alpha 7$ nicotinic acetylcholine receptor gene improves cognitive deficits and synaptic pathology in a mouse model of Alzheimer's disease. J Neurosci 29:8805-8815. CrossRef Medline

Ferreira ST, Klein WL (2011) The Abeta oligomer hypothesis for synapse failure and memory loss in Alzheimer's disease. Neurobiol Learn Mem 96:529-543. CrossRef Medline

Figueiredo CP, Clarke JR, Ledo JH, Ribeiro FC, Costa CV, Melo HM, MotaSales AP, Saraiva LM, Klein WL, Sebollela A, De Felice FG, Ferreira ST (2013) Memantine rescues transient cognitive impairment caused by high-molecular-weight abeta oligomers but not the persistent impairment induced by low-molecular-weight oligomers. J Neurosci 33:96269634. CrossRef Medline

Fischer MJ (2010) Amine coupling through EDC/NHS: a practical approach. Methods Mol Biol 627:55-73. CrossRef Medline

Freir DB, Nicoll AJ, Klyubin I, Panico S, Mc Donald JM, Risse E, Asante EA, Farrow MA, Sessions RB, Saibil HR, Clarke AR, Rowan MJ, Walsh DM, Collinge J (2011) Interaction between prion protein and toxic amyloid beta assemblies can be therapeutically targeted at multiple sites. Nat Commun 2:336. CrossRef Medline

Gimbel DA, Nygaard HB, Coffey EE, Gunther EC, Laurén J, Gimbel ZA, Strittmatter SM (2010) Memory impairment in transgenic Alzheimer mice requires cellular prion protein. J Neurosci 30:6367-6374. CrossRef Medline

Gu Z, Yakel JL (2011) Timing-dependent septal cholinergic induction of dynamic hippocampal synaptic plasticity. Neuron 71:155-165. CrossRef Medline

Hajj GN, Arantes CP, Dias MV, Roffé M, Costa-Silva B, Lopes MH, PortoCarreiro I, Rabachini T, Lima FR, Beraldo FH, Prado MM, Linden R, Martins VR (2013) The unconventional secretion of stress-inducible protein 1 by a heterogeneous population of extracellular vesicles. Cell Mol Life Sci 70:3211-3227. CrossRef Medline

Hernandez CM, Dineley KT (2012) $\alpha 7$ nicotinic acetylcholine receptors in Alzheimer's disease: neuroprotective, neurotrophic or both? Curr Drug Targets 13:613-622. CrossRef Medline 
Hernandez CM, Kayed R, Zheng H, Sweatt JD, Dineley KT (2010) Loss of $\alpha 7$ nicotinic receptors enhances $\beta$-amyloid oligomer accumulation, exacerbating early-stage cognitive decline and septohippocampal pathology in a mouse model of Alzheimer's disease. J Neurosci 30:2442-2453. CrossRef Medline

Hung LW, Ciccotosto GD, Giannakis E, Tew DJ, Perez K, Masters CL, Cappai $\mathrm{R}$, Wade JD, Barnham KJ (2008) Amyloid- $\beta$ peptide $(\mathrm{A} \beta$ ) neurotoxicity is modulated by the rate of peptide aggregation: $A \beta$ dimers and trimers correlate with neurotoxicity. J Neurosci 28:11950-11958. CrossRef Medline

Ittner LM, Ke YD, Delerue F, Bi M, Gladbach A, van Eersel J, Wölfing H, Chieng BC, Christie MJ, Napier IA, Eckert A, Staufenbiel M, Hardeman E, Götz J (2010) Dendritic function of tau mediates amyloid-beta toxicity in Alzheimer's disease mouse models. Cell 142:387-397. CrossRef Medline

Jankowsky JL, Slunt HH, Ratovitski T, Jenkins NA, Copeland NG, Borchelt DR (2001) Co-expression of multiple transgenes in mouse CNS: a comparison of strategies. Biomol Eng 17:157-165. CrossRef Medline

Kessels HW, Nguyen LN, Nabavi S, Malinow R (2010) The prion protein as a receptor for amyloid-beta. Nature 466:E3-E4; discussion E4-E5. CrossRef Medline

Khachaturian ZS (1985) Diagnosis of Alzheimer's disease. Arch Neurol 42: 1097-1105. CrossRef Medline

Kudo W, Lee HP, Zou WQ, Wang X, Perry G, Zhu X, Smith MA, Petersen RB, Lee HG (2012) Cellular prion protein is essential for oligomeric amyloid-beta-induced neuronal cell death. Hum Mol Genet 21:11381144. CrossRef Medline

Lambert MP, Barlow AK, Chromy BA, Edwards C, Freed R, Liosatos M, Morgan TE, Rozovsky I, Trommer B, Viola KL, Wals P, Zhang C, Finch CE, Krafft GA, Klein WL (1998) Diffusible, nonfibrillar ligands derived from Abeta1-42 are potent central nervous system neurotoxins. Proc Natl Acad Sci U S A 95:6448-6453. CrossRef Medline

Larson M, Sherman MA, Amar F, Nuvolone M, Schneider JA, Bennett DA, Aguzzi A, Lesné SE (2012) The complex PrP(c)-Fyn couples human oligomeric Abeta with pathological tau changes in Alzheimer's disease. J Neurosci 32:16857-16871a. CrossRef Medline

Laurén J, Gimbel DA, Nygaard HB, Gilbert JW, Strittmatter SM (2009) Cellular prion protein mediates impairment of synaptic plasticity by amyloid-beta oligomers. Nature 457:1128-1132. CrossRef Medline

Lee KS, Magalhães AC, Zanata SM, Brentani RR, Martins VR, Prado MA (2001) Internalization of mammalian fluorescent cellular prion protein and N-terminal deletion mutants in living cells. J Neurochem 79:79-87. CrossRef Medline

Li S, Hong S, Shepardson NE, Walsh DM, Shankar GM, Selkoe D (2009) Soluble oligomers of amyloid Beta protein facilitate hippocampal longterm depression by disrupting neuronal glutamate uptake. Neuron 62: 788-801. CrossRef Medline

Lima FR, Arantes CP, Muras AG, Nomizo R, Brentani RR, Martins VR (2007) Cellular prion protein expression in astrocytes modulates neuronal survival and differentiation. J Neurochem 103:2164-2176. CrossRef Medline

Linden R, Martins VR, Prado MA, Cammarota M, Izquierdo I, Brentani RR (2008) Physiology of the prion protein. Physiol Rev 88:673-728. CrossRef Medline

Lopes MH, Hajj GN, Muras AG, Mancini GL, Castro RM, Ribeiro KC, Brentani RR, Linden R, Martins VR (2005) Interaction of cellular prion and stress-inducible protein 1 promotes neuritogenesis and neuroprotection by distinct signaling pathways. J Neurosci 25:11330-11339. CrossRef Medline

Magdesian MH, Nery AA, Martins AH, Juliano MA, Juliano L, Ulrich H, Ferreira ST (2005) Peptide blockers of the inhibition of neuronal nicotinic acetylcholine receptors by amyloid beta. J Biol Chem 280:3108531090. CrossRef Medline

Martins VR, Beraldo FH, Hajj GN, Lopes MH, Lee KS, Prado MA, Linden R (2010) Prion protein: orchestrating neurotrophic activities. Curr Issues Mol Biol 12:63-86. Medline

Martyn AC, De Jaeger X, Magalhães AC, Kesarwani R, Gonçalves DF, Raulic S, Guzman MS, Jackson MF, Izquierdo I, Macdonald JF, Prado MA, Prado VF (2012) Elimination of the vesicular acetylcholine transporter in the forebrain causes hyperactivity and deficits in spatial memory and long-term potentiation. Proc Natl Acad Sci U S A 109:17651-17656. CrossRef Medline
McKhann G, Drachman D, Folstein M, Katzman R, Price D, Stadlan EM (1984) Clinical diagnosis of Alzheimer's disease: report of the NINCDSADRDA Work Group under the auspices of Department of Health and Human Services Task Force on Alzheimer's Disease. Neurology 34:939 944. CrossRef Medline

Michalski B, Fahnestock M (2003) Pro-brain-derived neurotrophic factor is decreased in parietal cortex in Alzheimer's disease. Brain Res Mol Brain Res 111:148-154. CrossRef Medline

Miesenböck G, De Angelis DA, Rothman JE (1998) Visualizing secretion and synaptic transmission with $\mathrm{pH}$-sensitive green fluorescent proteins. Nature 394:192-195. CrossRef Medline

Mucke L, Selkoe DJ (2012) Neurotoxicity of amyloid beta-protein: synaptic and network dysfunction. Cold Spring Harb Perspect Med 2:a006338. CrossRef Medline

Orr-Urtreger A, Göldner FM, Saeki M, Lorenzo I, Goldberg L, De Biasi M, Dani JA, Patrick JW, Beaudet AL (1997) Mice deficient in the $\alpha 7$ neuronal nicotinic acetylcholine receptor lack $\alpha$-bungarotoxin binding sites and hippocampal fast nicotinic currents. J Neurosci 17:9165-9171. Medline

Ostapchenko VG, Makarava N, Savtchenko R, Baskakov IV (2008) The polybasic $\mathrm{N}$-terminal region of the prion protein controls the physical properties of both the cellular and fibrillar forms of PrP. J Mol Biol 383:1210-1224. CrossRef Medline

Ostapchenko VG, Beraldo FH, Guimaraes AL, Mishra S, Guzman M, Fan J, Martins VR, Prado VF, Prado MA (2013) Increased prion protein processing and expression of metabotropic glutamate receptor 1 in a mouse model of Alzheimer's disease. J Neurochem. Advance online publication. Retrieved September 12, 2013. doi:10.1111/jnc.12296. CrossRef Medline

Paula-Lima AC, Adasme T, SanMartín C, Sebollela A, Hetz C, Carrasco MA, Ferreira ST, Hidalgo C (2011) Amyloid beta-peptide oligomers stimulate RyR-mediated $\mathrm{Ca}^{2+}$ release inducing mitochondrial fragmentation in hippocampal neurons and prevent RyR-mediated dendritic spine remodeling produced by BDNF. Antioxid Redox Signal 14:1209-1223. CrossRef Medline

Paula-Lima AC, Brito-Moreira J, Ferreira ST (2013) Deregulation of excitatory neurotransmission underlying synapse failure in Alzheimer's disease. J Neurochem 126:191-202. CrossRef Medline

Prado VF, Martins-Silva C, de Castro BM, Lima RF, Barros DM, Amaral E, Ramsey AJ, Sotnikova TD, Ramirez MR, Kim HG, Rossato JI, Koenen J, Quan H, Cota VR, Moraes MF, Gomez MV, Guatimosim C, Wetsel WC, Kushmerick C, Pereira GS, Gainetdinov RR, Izquierdo I, Caron MG, Prado MA (2006) Mice deficient for the vesicular acetylcholine transporter are myasthenic and have deficits in object and social recognition. Neuron 51:601-612. CrossRef Medline

Querfurth HW, LaFerla FM (2010) Alzheimer's disease. N Engl J Med 362: 329-344. CrossRef Medline

Resenberger UK, Harmeier A, Woerner AC, Goodman JL, Müller V, Krishnan R, Vabulas RM, Kretzschmar HA, Lindquist S, Hartl FU, Multhaup G, Winklhofer KF, Tatzelt J (2011) The cellular prion protein mediates neurotoxic signalling of beta-sheet-rich conformers independent of prion replication. EMBO J 30:2057-2070. CrossRef Medline

Resenberger UK, Müller V, Munter LM, Baier M, Multhaup G, Wilson MR, Winklhofer KF, Tatzelt J (2012) The heat shock response is modulated by and interferes with toxic effects of scrapie prion protein and amyloid beta. J Biol Chem 287:43765-43776. CrossRef Medline

Roffé M, Beraldo FH, Bester R, Nunziante M, Bach C, Mancini G, Gilch S, Vorberg I, Castilho BA, Martins VR, Hajj GN (2010) Prion protein interaction with stress-inducible protein 1 enhances neuronal protein synthesis via mTOR. Proc Natl Acad Sci U S A 107:13147-13152. CrossRef Medline

Roffé M, Hajj GN, Azevedo HF, Alves VS, Castilho BA (2013) IMPACT is a developmentally regulated protein in neurons that opposes the eukaryotic initiation factor 2alpha kinase GCN2 in the modulation of neurite outgrowth. J Biol Chem 288:10860-10869. CrossRef Medline

Romano SA, Cordeiro Y, Lima LM, Lopes MH, Silva JL, Foguel D, Linden R (2009) Reciprocal remodeling upon binding of the prion protein to its signaling partner hop/STI1. FASEB J 23:4308-4316. CrossRef Medline

Santos TG, Beraldo FH, Hajj GN, Lopes MH, Roffe M, Lupinacci FC, Ostapchenko VG, Prado VF, Prado MA, Martins VR (2013) Laminingammal chain and stress inducible protein 1 synergistically mediate PrPC-dependent axonal growth via Ca2 + mobilization in dorsal root ganglia neurons. J Neurochem 124:210-223. CrossRef Medline 
Sebollela A, Freitas-Correa L, Oliveira FF, Paula-Lima AC, Saraiva LM, Martins SM, Mota LD, Torres C, Alves-Leon S, de Souza JM, Carraro DM, Brentani H, De Felice FG, Ferreira ST (2012) Amyloid-beta oligomers induce differential gene expression in adult human brain slices. J Biol Chem 287:7436-7445. CrossRef Medline

Shen H, Kihara T, Hongo H, Wu X, Kem WR, Shimohama S, Akaike A, Niidome T, Sugimoto H (2010) Neuroprotection by donepezil against glutamate excitotoxicity involves stimulation of alpha7 nicotinic receptors and internalization of NMDA receptors. Br J Pharmacol 161:127139. CrossRef Medline

Snyder EM, Nong Y, Almeida CG, Paul S, Moran T, Choi EY, Nairn AC, Salter MW, Lombroso PJ, Gouras GK, Greengard P (2005) Regulation of NMDA receptor trafficking by amyloid-beta. Nat Neurosci 8:1051-1058. CrossRef Medline

Solforosi L, Criado JR, McGavern DB, Wirz S, Sánchez-Alavez M, Sugama S, DeGiorgio LA, Volpe BT, Wiseman E, Abalos G, Masliah E, Gilden D, Oldstone MB, Conti B, Williamson RA (2004) Cross-linking cellular prion protein triggers neuronal apoptosis in vivo. Science 303:15141516. CrossRef Medline

Southworth DR, Agard DA (2011) Client-loading conformation of the Hsp90 molecular chaperone revealed in the cryo-EM structure of the human Hsp90:Hop complex. Mol Cell 42:771-781. CrossRef Medline

Townsend M, Shankar GM, Mehta T, Walsh DM, Selkoe DJ (2006) Effects of secreted oligomers of amyloid beta-protein on hippocampal synaptic plasticity: a potent role for trimers. J Physiol 572:477-492. CrossRef Medline

Tsutsui S, Hahn JN, Johnson TA, Ali Z, Jirik FR (2008) Absence of the cellular prion protein exacerbates and prolongs neuroinflammation in experimental autoimmune encephalomyelitis. Am J Pathol 173:10291041. CrossRef Medline

Um JW, Nygaard HB, Heiss JK, Kostylev MA, Stagi M, Vortmeyer A, Wisniewski T, Gunther EC, Strittmatter SM (2012) Alzheimer amyloid-beta oligomer bound to postsynaptic prion protein activates Fyn to impair neurons. Nat Neurosci 15:1227-1235. CrossRef Medline

Walsh DM, Klyubin I, Fadeeva JV, Cullen WK, Anwyl R, Wolfe MS, Rowan MJ, Selkoe DJ (2002) Naturally secreted oligomers of amyloid beta pro- tein potently inhibit hippocampal long-term potentiation in vivo. Nature 416:535-539. CrossRef Medline

Wang HY, Lee DH, D'Andrea MR, Peterson PA, Shank RP, Reitz AB (2000) beta-Amyloid(1-42) binds to alpha7 nicotinic acetylcholine receptor with high affinity. Implications for Alzheimer's disease pathology. J Biol Chem 275:5626-5632. CrossRef Medline

Wang HY, Stucky A, Liu J, Shen C, Trocme-Thibierge C, Morain P (2009) Dissociating $\beta$-amyloid from $\alpha 7$ nicotinic acetylcholine receptor by a novel therapeutic agent, S 24795, normalizes $\alpha 7$ nicotinic acetylcholine and NMDA receptor function in Alzheimer's disease brain. J Neurosci 29:10961-10973. CrossRef Medline

Wang HY, Bakshi K, Frankfurt M, Stucky A, Goberdhan M, Shah SM, Burns LH (2012) Reducing amyloid-related Alzheimer's disease pathogenesis by a small molecule targeting filamin A. J Neurosci 32:9773-9784. CrossRef Medline

Xie L, Helmerhorst E, Taddei K, Plewright B, Van Bronswijk W, Martins R (2002) Alzheimer's $\beta$-amyloid peptides compete for insulin binding to the insulin receptor. J Neurosci 22:RC221(1-5). Medline

You H, Tsutsui S, Hameed S, Kannanayakal TJ, Chen L, Xia P, Engbers JD, Lipton SA, Stys PK, Zamponi GW (2012) Abeta neurotoxicity depends on interactions between copper ions, prion protein, and $N$-methyl-Daspartate receptors. Proc Natl Acad Sci U S A 109:1737-1742. CrossRef Medline

Zanata SM, Lopes MH, Mercadante AF, Hajj GN, Chiarini LB, Nomizo R, Freitas AR, Cabral AL, Lee KS, Juliano MA, de Oliveira E, Jachieri SG, Burlingame A, Huang L, Linden R, Brentani RR, Martins VR (2002) Stress-inducible protein 1 is a cell surface ligand for cellular prion that triggers neuroprotection. EMBO J 21:3307-3316. CrossRef Medline

Zhang B, Gaiteri C, Bodea LG, Wang Z, McElwee J, Podtelezhnikov AA, Zhang C, Xie T, Tran L, Dobrin R, Fluder E, Clurman B, Melquist S, Narayanan M, Suver C, Shah H, Mahajan M, Gillis T, Mysore J, MacDonald ME, et al. (2013) Integrated systems approach identifies genetic nodes and networks in late-onset Alzheimer's disease. Cell 153:707-720. CrossRef Medline 